\title{
Size distributions and temporal variations of biological aerosol particles in the Amazon rainforest characterized by microscopy and real-time UV-APS fluorescence techniques during AMAZE-08
}

\author{
J. A. Huffman ${ }^{1,2}$, B. Sinha ${ }^{3,4}$, R. M. Garland ${ }^{2, *}$, A. Snee-Pollmann ${ }^{3, * *}$, S. S. Gunthe ${ }^{2, * * *}$, P. Artaxo ${ }^{5}$, S. T. Martin ${ }^{6}$, \\ M. O. Andreae ${ }^{2}$, and U. Pöschl ${ }^{2}$ \\ ${ }^{1}$ University of Denver, Department of Chemistry and Biochemistry, Denver, CO, USA \\ ${ }^{2}$ Max Planck Institute for Chemistry, Biogeochemistry Department, Mainz, Germany \\ ${ }^{3}$ Max Planck Institute for Chemistry, Particle Chemistry Department, Mainz, Germany \\ ${ }^{4}$ IISER Mohali, Department of Earth Sciences, S. A. S. Nagar, Manauli PO, India \\ ${ }^{5}$ Instituto de Fisica, Universidade de Sao Paulo, Sao Paulo, Brazil \\ ${ }^{6}$ Harvard University, School of Engineering and Applied Sciences \& Department of Earth and Planetary Sciences, \\ Cambridge, MA, USA \\ *now at: Council for Scientific and Industrial Research (CSIR), Natural Resources and the Environment, \\ Pretoria, South Africa \\ ** now at: Roche Diagnostics GmbH, Pharma Research and Early Development, Penzberg, Germany \\ *** now at: Indian Institute for Technology Madras, Department of Civil Engineering \& EWRE Division, Chennai-36, India
}

Correspondence to: J. A. Huffman (alex.huffman@du.edu)

Received: 6 September 2012 - Published in Atmos. Chem. Phys. Discuss.: 24 September 2012

Revised: 7 December 2012 - Accepted: 10 December 2012 - Published: 18 December 2012

\begin{abstract}
As a part of the AMAZE-08 campaign during the wet season in the rainforest of central Amazonia, an ultraviolet aerodynamic particle sizer (UV-APS) was operated for continuous measurements of fluorescent biological aerosol particles (FBAP). In the coarse particle size range $(>1 \mu \mathrm{m})$ the campaign median and quartiles of FBAP number and mass concentration were $7.3 \times 10^{4} \mathrm{~m}^{-3}\left(4.0-13.2 \times 10^{4} \mathrm{~m}^{-3}\right)$ and $0.72 \mu \mathrm{g} \mathrm{m}^{-3}\left(0.42-1.19 \mu \mathrm{g} \mathrm{m}^{-3}\right)$, respectively, accounting for $24 \%(11-41 \%)$ of total particle number and $47 \%$ (25-65\%) of total particle mass. During the five-week campaign in February-March 2008 the concentration of coarsemode Saharan dust particles was highly variable. In contrast, FBAP concentrations remained fairly constant over the course of weeks and had a consistent daily pattern, peaking several hours before sunrise, suggesting observed FBAP was dominated by nocturnal spore emission. This conclusion was supported by the consistent FBAP number size distribution peaking at $2.3 \mu \mathrm{m}$, also attributed to fungal spores and mixed biological particles by scanning electron microscopy (SEM), light microscopy and biochemical staining. A second
\end{abstract}

primary biological aerosol particle (PBAP) mode between 0.5 and $1.0 \mu \mathrm{m}$ was also observed by SEM, but exhibited little fluorescence and no true fungal staining. This mode may have consisted of single bacterial cells, brochosomes, various fragments of biological material, and small Chromalveolata (Chromista) spores. Particles liquid-coated with mixed organic-inorganic material constituted a large fraction of observations, and these coatings contained salts likely from primary biological origin. We provide key support for the suggestion that real-time laser-induce fluorescence (LIF) techniques using $355 \mathrm{~nm}$ excitation provide size-resolved concentrations of FBAP as a lower limit for the atmospheric abundance of biological particles in a pristine environment. We also show some limitations of using the instrument for ambient monitoring of weakly fluorescent particles $<2 \mu \mathrm{m}$. Our measurements confirm that primary biological particles, fungal spores in particular, are an important fraction of supermicron aerosol in the Amazon and that may contribute significantly to hydrological cycling, especially when coated by mixed inorganic material. 


\section{Introduction}

Biogenic gases and particles emitted into the atmosphere by plants and organisms on the Earth's surface can have a wideranging influence on a number of natural systems and are important for study by a multitude of scientific disciplines. Primary biological aerosol particles (PBAP), a subset of biogenic particles often referred to as bioaerosols, consist of biological material such as bacteria, fungal spores, pollen, vegetative detritus, and their fragments and excretions. PBAP can be living or dead and their size can span physical dimensions of a few nanometers to hundreds of micrometers. They are crucial to the reproductive processes of many organisms because they spread genetic material over long distances. They can also negatively affect agricultural and public health as pathogenic agents, can be used as agents of biological warfare, and can affect atmospheric systems by acting as nuclei on which cloud water droplets and ice particles may form (Cox and Wathes, 1995; Pöschl, 2005; Jaenicke et al., 2007; Prenni et al., 2009; Després et al., 2012). Several studies published by Jaenicke and colleagues indicate the global ubiquity of bioaerosols and suggested that atmospheric study of PBAP is critical to understanding aspects of atmospheric processes (e.g., Jaenicke et al., 2007). In particular they reported that, within the size range measured $(>0.2 \mu \mathrm{m})$, PBAP concentrations varied from $0.6 \mathrm{~cm}^{-3}$ in remote continental and coastal marine sites to $\sim 3 \mathrm{~cm}^{-3}$ at a semi-urban European site, thus representing up to $25 \%$ of the total particle number concentration (Matthias-Maser and Jaenicke, 1995, 2000; Jaenicke et al., 2007). While quantitative estimates vary significantly, PBAP has consistently been shown to be an important fraction of atmospheric particulate matter (e.g., Kenny and Jennings, 1998; Elbert et al., 2007; Bauer et al., 2008; Wiedinmyer et al., 2009; Womack et al., 2010; Després et al., 2012). Microorganisms have also been shown to be transported long distances in plumes of desert dust from Asia and Africa (e.g., Griffin et al., 2007; Polymenakou et al., 2008; Hallar et al., 2011). In addition to measurements of their total atmospheric concentrations, bioaerosol properties of certain organisms have been studied for their ability to nucleate ice at temperatures well above the homogenous freezing point (ca. $-38^{\circ} \mathrm{C}$ ) of cloud droplets (Schnell and Vali, 1972, 1973; Yankofsky et al., 1981; Ariya and Amyot, 2004; Möhler et al., 2007; Bowers et al., 2009; Prenni et al., 2009; Morris et al., 2012) and to act as giant cloud condensation nuclei (GCCN) (Möhler et al., 2007; Barahona et al., 2010). In part motivated by the desire to constrain the understanding of the geographic spread and climatic importance of PBAP, a number of recent works have presented regional or global modeling studies of biological particles in the atmosphere (Helbig et al., 2004; Burrows et al., 2009a, b; Heald and Spracklen, 2009; Hoose et al., 2010; Sesartic and Dallafior, 2011; Sesartic et al., 2012). These are important steps in determining the effects that bioaerosols have on various Earth and human sys- tems, but uncertainties in measurements input to these models are still large.

The application of laser/light-induced fluorescence (LIF) methods to on-line detection of bioaerosols within the last two decades has vitalized interest within the atmospheric science community by enabling real-time analyses with much higher time and particle size resolution than had been previously attainable (e.g., Pinnick et al., 1995; Hairston et al., 1997; Seaver et al., 1999; Sivaprakasam et al., 2004; Kaye et al., 2005; Pan et al., 2011; Healy et al., 2012). Though many instruments have been developed for use by individual research groups or for military applications, the ultraviolet aerodynamic particle sizer (UV-APS) was the first such instrument to be commercially available for research use. The UV-APS utilizes a pulsed $355 \mathrm{~nm}$ Nd:YAG laser for excitation and detects emitted fluorescence in a single wavelength channel $(420-575 \mathrm{~nm})$ from particles entrained into the instrument (Hairston et al., 1997; Brosseau et al., 2000). The excitation wavelength used was originally chosen to enable rapid detection of molecules linked to cellular metabolism (e.g., NAD(P)H and riboflavin; Harrison and Chance, 1970; Eng et al., 1989; Li et al., 1991), though other biological molecules not associated with active metabolism are also likely to fluoresce at these wavelengths under many conditions (Pöhlker et al., 2012a). The UV-APS has been tested in the laboratory to determine cell viability (Agranovski et al., 2003b; Laflamme et al., 2005) and to measure bacteria (Brosseau et al., 2000; Agranovski et al., 2003a, b; Jung et al., 2010) and fungal spores (Kanaani et al., 2007, 2008a, b; Lee et al., 2010) in real-time. Huffman et al. (2010) reported the application of the instrument to long-term (4-months) ambient sampling and reported trends of bioaerosols for a measurement site in central Europe. In the same manuscript the fluorescent signal detected by the UV-APS in such ambient settings was defined as fluorescent biological aerosol particles (FBAP), and the abundance of FBAP was discussed as providing an approximate lower limit for the actual abundance of PBAP.

Tropical rainforest environments in several areas of the globe have often been seen as windows to observe relatively clean, natural emissions from the biosphere (Andreae, 2007). In particular many collaborative measurement studies in the Amazon rainforest of Brazil within the last decades have helped to advance the state of aerosol science and understanding of forest-atmosphere exchange processes (Artaxo et al., 1988; Harriss et al., 1990; Artaxo and Hansson, 1995; Andreae and Crutzen, 1997; Andreae et al., 2002; Graham et al., 2003a; Guyon et al., 2003; Martin et al., 2010a, b). In-situ measurements have repeatedly suggested the presence of a high fraction of biogenic particles within tropical rainforest air (e.g., Echalar et al., 1998; Gilardoni et al., 2011). Artaxo et al. $(1988,1995)$ proposed that the Amazon basin was as a significant producer of PBAP, and Guyon et al. (2003) suggested that not only was the region the world's largest rainforest but also that it was therefore also likely the 
largest global source of biogenic gases and particles. Pöschl et al. (2010) stated that there was a dominance of biogenic sources for all ranges of particles sizes observed within the Amazon and suggested that such forests can be seen as biogeochemical reactors, where the regional biosphere initiates a feedback loop of rain and biological growth. Even more specifically, rainforests have been reported as huge sources of fungal spores by many publications. For example Elbert et al. (2007) reported measurements from near Balbina, Brazil suggesting that local fungal spores contributed an average of $\sim 35 \%$ of coarse particles by number, and Zhang et al. (2010) estimated the fraction at $\sim 20 \%$ of $\mathrm{PM}_{10}$ in a tropical rainforest on Hainan Island near China. Prenni et al. (2009) highlighted the ability of biogenic emissions from the Amazon to nucleate ice at temperatures higher than was observed for mineral dust and suggest that concentrations of atmospheric ice nuclei (IN) can almost entirely be explained by local emissions of biological particles.

The Amazonian Aerosol Characterization Experiment (AMAZE-08) took place during the wet season of FebruaryMarch 2008 (Martin et al., 2010a) and was the basis for a number of recent studies on the sources and properties of biogenic aerosol particles in the Amazon (Chen et al., 2009; Gunthe et al., 2009; Prenni et al., 2009; Pöschl et al., 2010; Ebben et al., 2011; Schneider et al., 2011). Here we report observations from the UV-APS instrument operated for realtime, in-situ detection and sizing of FBAP throughout the campaign. We also report on the results of complementary microscopic analyses of PBAP on filter samples collected concurrently with direct aerosol measurements.

\section{Methods}

\subsection{Amazonian measurement site}

Measurements were carried out as a part of the Amazonian Aerosol Characterization Experiment (AMAZE-08) within pristine rainforest of the Reserva Biológica do Cuieiras, located in the central Amazon Basin and $60 \mathrm{~km} \mathrm{NNW}$ of downtown Manaus, Brazil (Martin et al., 2010a). A PM 10 inlet was placed at the top of a $40 \mathrm{~m}$ tower (TT34) at approximately tree canopy height $\left(2^{\circ} 35.7^{\prime} \mathrm{S}, 60^{\circ} 12.6^{\prime} \mathrm{W}\right.$, $110 \mathrm{~m}$ a.s.l.). Sampled air was brought via stainless-steel tubing (0.75-inch outer diameter) to instrumentation and equipment in a ground-level container and then dried to between $20-40 \%$ relative humidity $(\mathrm{RH})$ using silica gel driers (Tuch et al., 2009). Calculations based on operating conditions within the sampling line suggested that the flow was laminar at all times providing an aerodynamic particle diameter $\left(D_{\mathrm{a}}\right)$ upper cut-off of $\sim 7 \mu \mathrm{m}$. Sampling took place between 2 February and 15 March 2008 during the Amazonian wet season, when biomass burning is typically reduced, in order to minimize interference by plumes due to anthropogenic burning activity. All times presented here are listed as local time (LT) at the sampling site, which is four hours behind Coordinated Universal Time (UTC) (i.e., local time $=$ UTC $-4 h)$.

\subsection{Real-time fluorescence measurement}

An ultraviolet aerodynamic particle sizer (TSI, Inc. Model 3314) was utilized during this study for measurement of biological particles in pristine Amazonian air masses. Details of the instrument, including operating principles and field operation and data analysis procedures are discussed in detail elsewhere (Hairston et al., 1997; Brosseau et al., 2000; Huffman et al., 2010). The instrument performs aerodynamic particle sizing $\left(D_{\mathrm{a}}\right)$ in the diameter range of $0.5-20 \mu \mathrm{m}$ over 52 channels, and the spectrally unresolved intensity of total fluorescence is recorded for each incoming particle into one of 64 channels. Thus, each sample provides a 3-dimensional cube of information (particle number, diameter, and fluorescence). Summing particle number within each size bin over all fluorescence channels results in a size distribution of the total particle number concentration, which is analogous to the output of a standard APS instrument. Particles were considered non-fluorescent when their emitted fluorescent signal was recorded in one of the first two channels, and fluorescent biological aerosol particles when recorded in channels 3-64. The particle counting efficiency of the UV-APS drops below unity at $D_{\mathrm{a}}<0.7 \mu \mathrm{m}$, and interferences from non-biological particles below $1.0 \mu \mathrm{m}$ may be more likely (Huffman et al., 2010). As a result, $1.0 \mu \mathrm{m}$ is utilized here as the lower-limit for biological particles measured by this technique, and for the purposes of this manuscript this size also represents the border between fine $(<1 \mu \mathrm{m})$ and coarse $(>1 \mu \mathrm{m})$ modes of the particle size distribution. This distinction is reflected in the nomenclature of subscripts within the text: the letter "c" refers to coarse particles, "F" to fluorescent particles, and "T" to total particles. For example, $N_{\mathrm{T}, \mathrm{c}}$ refers to the integrated number concentration of coarse particles. Unit-normalized mass concentrations were estimated using the number concentration provided by the UV-APS and a density of $1 \mathrm{~g} \mathrm{~cm}^{-3}$.

The UV-APS was operated in standard flow mode, with a total sampled volumetric flow rate of $5.0 \mathrm{~L} \mathrm{~min}^{-1}(\mathrm{lpm})$ at atmospheric pressure and temperature. This flow was split within the instrument into a sampled flow of $1.0 \mathrm{lpm}$ and a sheath flow of the remaining $4.0 \mathrm{lpm}$ by utilizing pressuredifference feedback control. Measurements were initiated every $5 \mathrm{~min}$ and integrated over a sample length of $299 \mathrm{~s}$, achieving a total of 8734 sampling points during AMAZE08. Several large gaps occur in the campaign time series (e.g., Fig. 1) and are a result of instrument down time due to operational issues, general power failures, or inlet line problems (Martin et al., 2010a). 


\subsection{Sample collection for microscopic analysis}

Aerosol samples for microscopic analysis were collected via the same laminar flow inlet through a two-stage stacked filter unit using $12 \mathrm{~mm}$ Nuclepore polycarbonate filters precoated with sputtered gold and with a pore size of $5 \mu \mathrm{m}$ for coarse particles and $0.2 \mu \mathrm{m}$ for fine particles, respectively. However, every particle was counted and sized individually and the definition of coarse $>1 \mu \mathrm{m}$ and fine $<1 \mu \mathrm{m}$ volume equivalent diameter is adhered to for particles counted using the SEM. The volumetric flow through the stacked filter unit was nominally $1 \mathrm{lpm}$ and air was collected for approximately 24 continuous hours for each sample. The flow rate was controlled using a needle valve and the accuracy of the flow was checked using a primary flow-meter (Gilian Gilibrator, Sensidyne, LP) before removing and after installing a sample. Due to difficulties with the needle valve, the flow measured before changing the filter was lower than the nominal flow; therefore, the actual flow rates and sample volumes may have been smaller than the nominal value (deviations up to $\sim 30 \%$ ). This uncertainty may explain certain discrepancies in absolute concentration when compared with the realtime measurements made in parallel. This uncertainty, however, did not affect results of microscopy analysis regarding the relative proportions of particle types.

\subsection{Semi-automated scanning electron microscopy analysis}

Aerosol particles were post-analyzed by scanning electron microscopy (SEM) using the secondary electron in-lens detector of a high-performance field emission microscope with a first generation Gemini Column (LEO 1530 FESEM) at an acceleration voltage of $10 \mathrm{keV}$ and a working distance of $9 \mathrm{~mm}$. The in-lens detector enabled detection of thin organic coatings and organic particles thinly deposited on the filters, which are not usually observed with other detectors. The elemental composition of inorganic components was characterized using a combination of the Oxford Instruments ultra-thin-window energy-dispersive x-ray (EDX) detector and subsequent NanoSIMS (nanoscale secondary ion mass spectrometry) analysis on selected particles. The chemical nature of organic droplets and mixed organic-inorganic particles was confirmed by NanoSIMS analysis as detailed below.

The filter samples were scanned using a semi-automated spot counting technique, which had been evaluated using NIST 2783 air particulate matter on filter media, as described in Sinha et al. (2008). Filters were scanned with a dwell time of $16.5 \mu$ pixel $^{-1}$ and $500 \times 500$ pixels per image at a magnification of $6500 \times$ (pixel size $88.9 \mathrm{~nm}$ ) for coarse and $19500 \times$ (pixel size $29.6 \mathrm{~nm}$ ) for fine filters. Particles located on predefined equidistant spots of the counting grid were counted and high resolution images were acquired for those particles. The recorded data were used to classify the particles according to size, composition and mixing state. Mixing state is a term used to distinguish externally mixed particles found only as separate entities (e.g. PBAP or particles containing pure organic material) from internally mixed particles where mixtures of two or more components are found in the same particle (e.g. PBAP with organic/inorganic coating). Using this spot counting technique, the probability for a particle of a certain size and type to be counted is directly proportional to the two-dimensional (2-D) surface area of the particle and the fraction of the filter surface covered by the particles. This relationship is used to upscale the counting results from the scanned filter area to the total filter area. More than 6400 points $(>0.6 \%$ of the total filter area) were investigated for coarse filters and more than 2500 points $(>0.07 \%$ of the total filter area) for fine filters, leading to an average particle count of 110 coarse and 350 fine mode particles per air sample (filter pair). The 2-D surface area of a particle was measured by counting the number of pixels the particle occupied in the secondary electron image and used to calculate the 2-D equivalent diameter, taken as the diameter of a circle having the same surface area. For particles coated by organic material, the 2-D surface area and equivalent diameters were determined both for the insoluble core (black carbon, mineral dust or primary biological and for the composite particle (core and organic coating). The average footprint to height ratio of each particle type was determined for a small subset of particles using atomic force microscopy for fine mode and the fine focus of the SEM for coarse mode particles. This information was used to convert the 2-D equivalent diameter to a volume equivalent diameter. The size determination was performed on separately acquired high resolution images (pixel size $0.6 \mathrm{~nm}$ to $15 \mathrm{~nm}$ ). SEM size distributions are also based on volume equivalent diameter, which should be similar to aerodynamic equivalent diameter for PBAP (density $\sim 1 \mathrm{~g} \mathrm{~cm}^{-3}$ ) but differs by a factor of 1.6 from the aerodynamic equivalent diameter for mineral dust with a density of $\sim 2.1-2.7 \mathrm{~g} \mathrm{~cm}^{-3}$. Shape factors also need to be considered while converting volume equivalent diameter into aerodynamic diameter. However, due to the complexity of some of the observed shapes we refrained from attempting such a conversion.

Unit-normalized particle mass is reported in all cases here assuming unit density $\left(1 \mathrm{~g} \mathrm{~cm}^{-3}\right)$ for all particle types. While this normalization leads to an underestimate of total mass concentration for most particle types, it provides a first approximation for particle mass directly proportional to particle volume.

\subsection{NanoSIMS}

Chemical analysis of aerosol particles was performed using a Cameca NanoSIMS 50 ion microprobe in multi-collection detector mode by sputtering the sample with a $\sim 1 \mathrm{pACs}^{+}$ primary ion beam focused into a spot of $\sim 100 \mathrm{~nm}$ diameter. The primary ion beam was scanned several times over an area of $10 \mu \mathrm{m} \times 10 \mu \mathrm{m}$, with a dwell time of $1000 \mu \mathrm{sixel}^{-1}$, 
and images $(256 \times 256$ pixels $)$ were recorded for every scan. The detector dead time was $44 \mathrm{~ns}$ and the count rates were corrected accordingly. The energy band-pass slit was set to $20 \mathrm{eV}$, the entrance slit and aperture slit were decreased to $30 \times 180 \mu \mathrm{m}$ and $200 \times 200 \mu \mathrm{m}$, respectively, and the transmission was kept at $50 \%$ to enhance the count rate on small particles. To remove surface contaminations, all images were pre-sputtered for one cycle followed by 10 cycles of analysis.

Secondary ions of ${ }^{12} \mathrm{C}^{-},{ }^{16} \mathrm{O}^{-},{ }^{12} \mathrm{C}^{14} \mathrm{~N}^{-},{ }^{32} \mathrm{~S}^{-}$and ${ }^{37} \mathrm{Cl}^{-}$ were simultaneously collected in five electron multipliers. We display qualitative images of the counts per pixels for each of these species. Such images provide an indication of the absence/presence of the element in certain parts of the aerosol particles but the data is not corrected for isotope abundances (we monitored the major masses for $\mathrm{C}, \mathrm{O}, \mathrm{CN}$ and $\mathrm{S}$ but a minor mass for $\mathrm{Cl}$ ) and is not calibrated.

\subsection{Staining and light microscopy of fungi}

Filters were mounted on glass microscopy slides and particles were stained with lactophenol blue solution (Sigma Aldrich, Inc.) to selectively highlight chitin molecules within the cells walls of fungal material. This technique targets Eumycota (true fungi), but will not identify spores with cellulose-based cell walls, such as those of Chromalveolata (Chromista), a kingdom which evolved separately from the common ancestors of plants, animals and fungi and including Peronosporomycetes such as Phytophthora spp. that can also form air-borne, pathogenic spores (Bartnicki-Garcia, 1968; Judelson and Blanco, 2005). For this analysis, a small drop of the solution was placed on top of the filter using a micropipette, and the cover slip was gently lowered onto the filter to avoid trapping air between the filter and the cover slip. The cover slip was then sealed using nail polish and the specimen was investigated immediately under the light microscope (Axio Scope, Carl Zeiss) at a magnification of $50 \times$ in transmitted light mode. Images were recorded using a digital Camera (CAM-SC30, Olympus Europa Holding $\mathrm{GmbH}$ ) coupled to the Cell^P software package (Olympus Europa Holding $\mathrm{GmbH}$ ). The investigations were carried out on the gold-coated filters used for collecting SEM samples, because no separate samples were collected for this analysis. Thus, due to multiple reflections on the gold and interferences caused by high particle loadings, very few filters (samples M04, M08, M12) could be successfully investigated by the fungal stain procedure. Of these only one sample (M12) allowed successful analysis of both fine and coarse filters. One quarter of the area of each punch was analyzed for samples M08 and M12, and this approach resulted in a slight increase in quantitative uncertainty for these samples. Image analysis and particle sizing were performed using Image J software.

\subsection{Focus period definition}

For more quantitative contrast between early and late periods of the AMAZE-08 campaign, SEM analysis of filter samples allowed assignment of specific filter periods within either Low Dust focus (samples M04, M08, M12) or High Dust focus (M02, M07, M30) categories (see Sect. S1.1 for sample dates and times). These SEM analysis-derived definitions are also consistent with similar periods as defined using other techniques from the AMAZE-08 campaign (Gunthe et al., 2009; Martin et al., 2010a; Pöschl et al., 2010).

\section{Results and discussion}

\subsection{Measurement period overview}

Over the course of the AMAZE-08 measurement period, observed particles were dominated by natural sources, and the relative contribution of aerosol particles from anthropogenic activity and biomass burning was low. Concentrations of airborne mineral dust from long-range transport were episodic and were more common within the first half of the campaign. The second half can be characterized as representing clean air masses that were relatively free of biomass burning and mineral dust plumes (Chen et al., 2009; Martin et al., 2010a) and is thus more representative of pristine emissions directly from the forest (Pöschl et al., 2010). Figure 1 shows number and mass concentrations, as well as size distributions, from each 5-min UV-APS sample for the full measurement period of AMAZE-08. The clean air late in the campaign is highlighted by the lower integrated total number and mass concentrations after 4 March $\left(N_{\mathrm{T}, \mathrm{c}}, M_{\mathrm{T}, \mathrm{c}} ;\right.$ Fig. 1a, c). Occasional periods of high total particle concentrations still occurred during this period (e.g., afternoons of 5 March and $8 \mathrm{March}$ ), but these periods were much shorter in duration and much weaker than events during the first three weeks of February (Fig. 1a, c). In contrast, FBAP concentrations were relatively consistent throughout the campaign as were FBAP size distributions, indicating that the UV-APS signal was not heavily influenced by the episodic nature of non-fluorescent particle arrival.

Average size distributions for the entire campaign are shown in Fig. 2. The total number peaks below $1 \mu \mathrm{m}$, with a long tail at larger sizes and a second broad peak at approximately $2.1 \mu \mathrm{m}$. The apparent peak at $0.7 \mu \mathrm{m}$ is a result of diminishing instrument transmission efficiency within the entrance nozzle. Particles smaller than $\sim 0.7 \mu$ m do not enter the UV-APS efficiently and are lost due to diffusion within the instrument inlet, causing an apparent peak in the size distribution. The actual maxima in the number size distribution are at about $70 \mathrm{~nm}$ and $150 \mathrm{~nm}$ (Martin et al., 2010a; Pöschl et al., 2010). At sizes larger than $0.7 \mu \mathrm{m}$, the campaignaverage size distribution acquired from the UV-APS is in good agreement with size distributions measured in parallel 

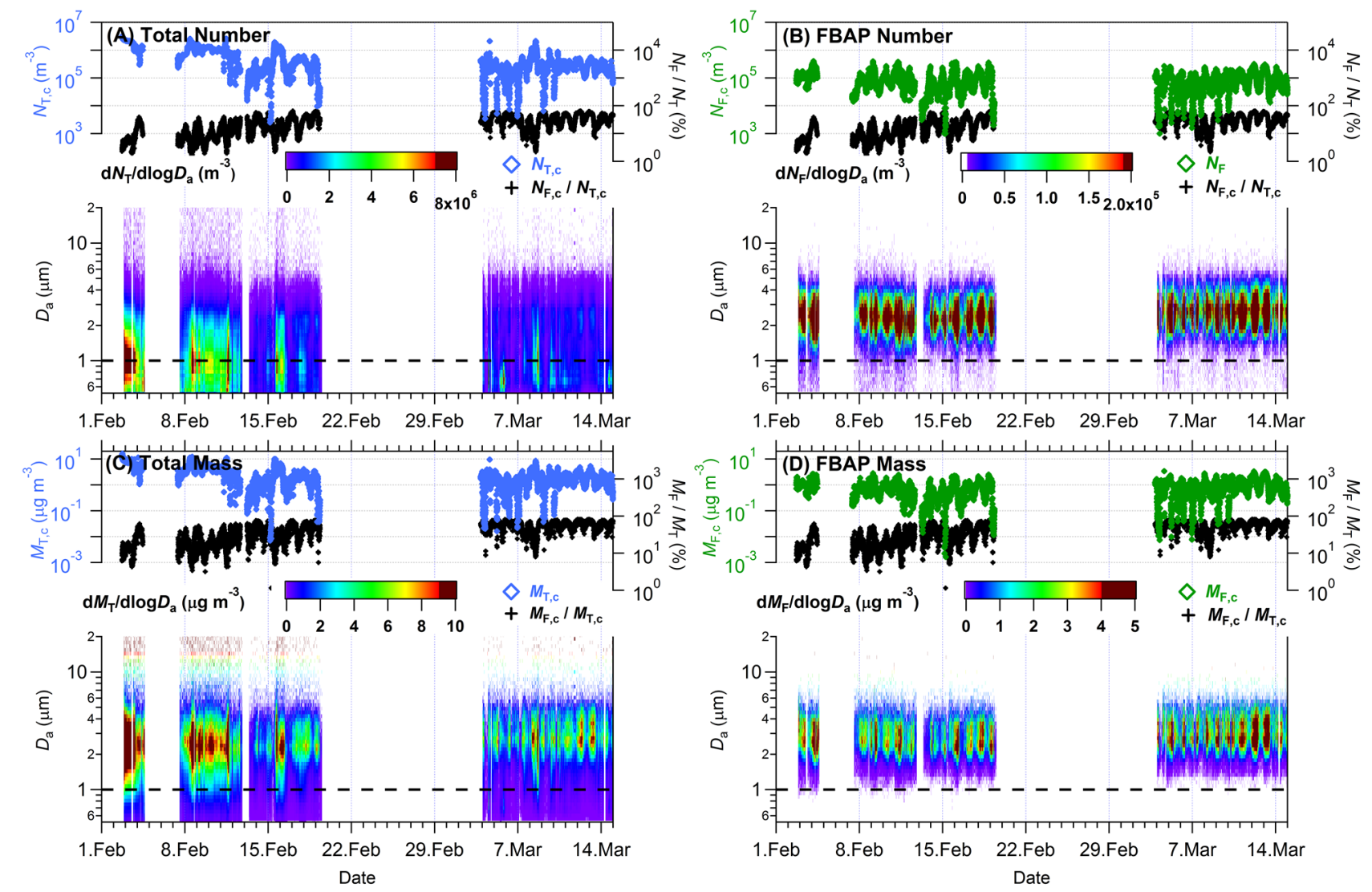

Fig. 1. Time series of particle concentrations. Each panel: integrated values (upper left), ratio of fluorescent to total (upper right), and sizeresolved measurements. (A) total number $\left(N_{\mathrm{T}, \mathrm{c}}\right),(\mathbf{B})$ FBAP number $\left(N_{\mathrm{F}, \mathrm{c}}\right),(\mathbf{C})$ total mass $\left(M_{\mathrm{T}, \mathrm{c}}\right),(\mathbf{D})$ FBAP mass $\left(M_{\mathrm{F}, \mathrm{c}}\right)$. Dashed line at $1 \mu \mathrm{m}$ indicates lower bound of number integration; mass is unit-normalized.

by other techniques (Martin et al., 2010a; Fig. 12). Particles larger than $7 \mu \mathrm{m}$ were not transmitted efficiently through the laminar-flow inlet lines. The average mass size distribution of total particles (Fig. 2a) exhibits a broad peak at $\sim 2.5 \mu \mathrm{m}$, as well as a secondary peak at a slightly larger size and a long tail to the left. To reflect more accurate mass distributions, the unit-normalized mass distributions in $D_{\text {a }}$ presented here would be expected to shift to larger particle size, with increased area under the curve; $D_{\mathrm{a}}$ is proportional to the square root of particle density (DeCarlo et al., 2004).

The campaign average size distributions of FBAP number and mass have much narrower peaks than do the total particle distributions, dominated in number by a peak at $2.3 \mu \mathrm{m}$ and in mass by a set of multi-mode peaks from 2 to $5 \mu \mathrm{m}$. The secondary peak at $2.1 \mu \mathrm{m}$ in the total number distribution (Fig. 2a) occurs at the same diameter as the dominant peak in the FBAP number distribution (Fig. 2c). Thus, the location of this peak in the total particle distribution may indicate that biological material is the cause of most of this particle mode, but only an average of $62 \%$ of the peak is counted as fluorescent (discussed further in Sect. 3.3 and with Fig. 10). The FBAP fraction of the dominant particle mode observed here increases during periods less influenced by mineral dust, as discussed in Sect. 3.2. The overall appearance of the average FBAP number distribution is similar to what has been reported previously at two other measurement locations. For a semi-urban location in central Europe, Huffman et al. (2010) reported an average FBAP peak at $3.2 \mu \mathrm{m}$. For a tropical rainforest site in Borneo, Gabey et al. (2010) observed a qualitatively similar peak at $2.5 \mu \mathrm{m}$. Artaxo and Hansson (1995) reported a coarse mode $D_{50}$ at $3.0 \mu \mathrm{m}$ for biogenic particles collected on cascade impactors at a remote Amazon site as determined via elemental analysis. MatthiasMaser and Jaenicke $(1995,2000)$, however, reported a PBAP size distribution $(<10 \mu \mathrm{m})$ with monotonically decreasing slope based on microscopy of impactor samples.

The campaign average size-resolved ratio of FBAP to total particles (Fig. 3) indicates that the largest fraction of fluorescent biological particles occurs between $\sim 2-7 \mu \mathrm{m}$, with sloping tails on either side. The fact that ratio is approximately zero for particle sizes below $\sim 1.3 \mu \mathrm{m}$ is consistent, by extrapolation, with previous observations that primary biological particles comprise only a very small fraction of Amazonian submicron aerosol (Chen et al., 2009; Pöschl et 

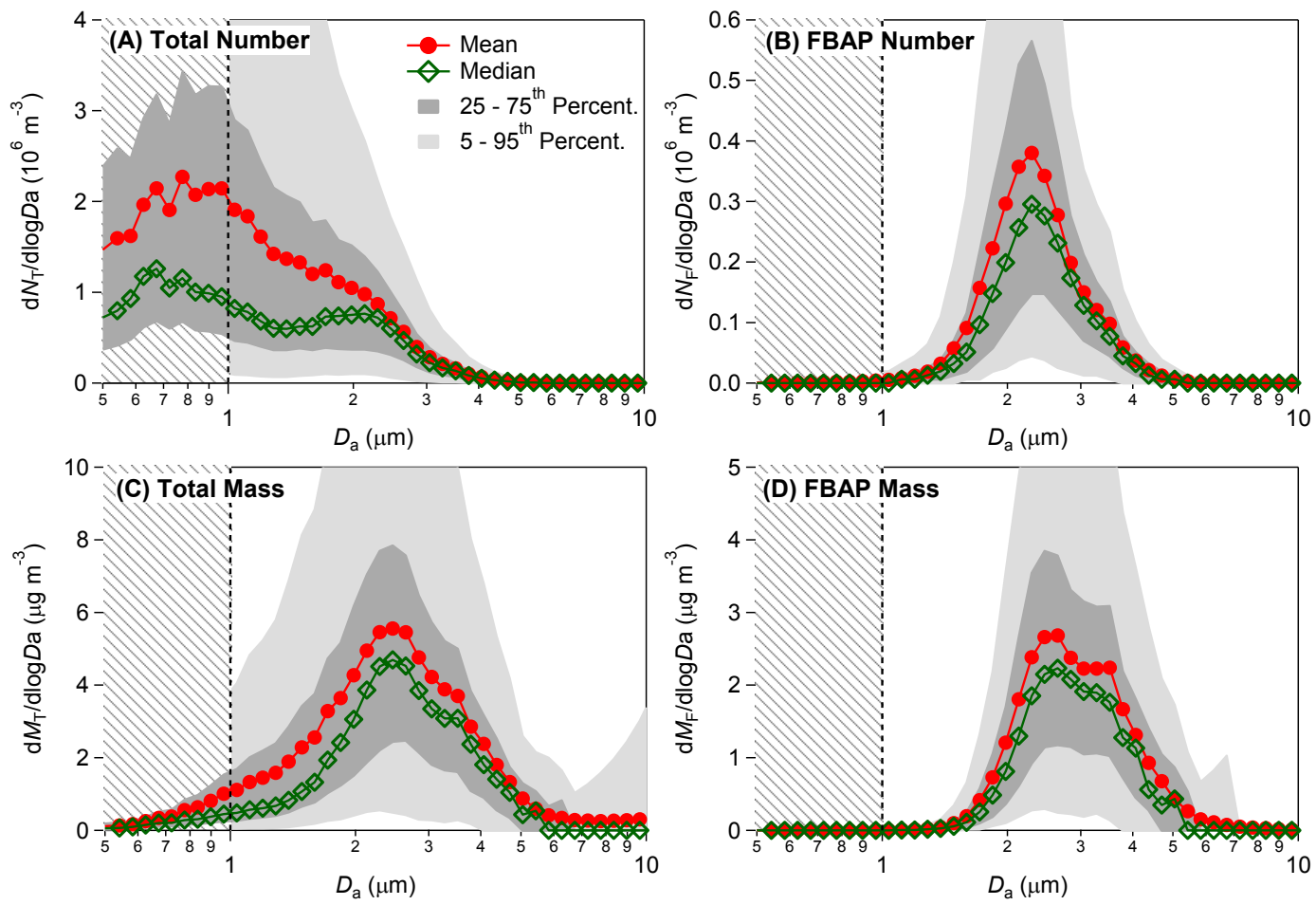

Fig. 2. Average particle number and unit-normalized mass size distributions for the measurement campaign (all points in Fig. 1). Hatched area indicates that only particles larger than $1.0 \mu \mathrm{m}$ were integrated for number and mass concentrations. (A) total number $\left(\mathrm{d} N_{\mathrm{T}} / \mathrm{d} \log D_{\mathrm{a}}\right)$, (B) FBAP number $\left(\mathrm{d} N_{\mathrm{T}} / \mathrm{d} \log D_{\mathrm{a}}\right)$, (C) total mass $\left(\mathrm{d} M_{\mathrm{T}} / \mathrm{d} \log D_{\mathrm{a}}\right)$, (D) FBAP mass $\left(\mathrm{d} M_{\mathrm{F}} / \mathrm{d} \log D_{\mathrm{a}}\right)$.

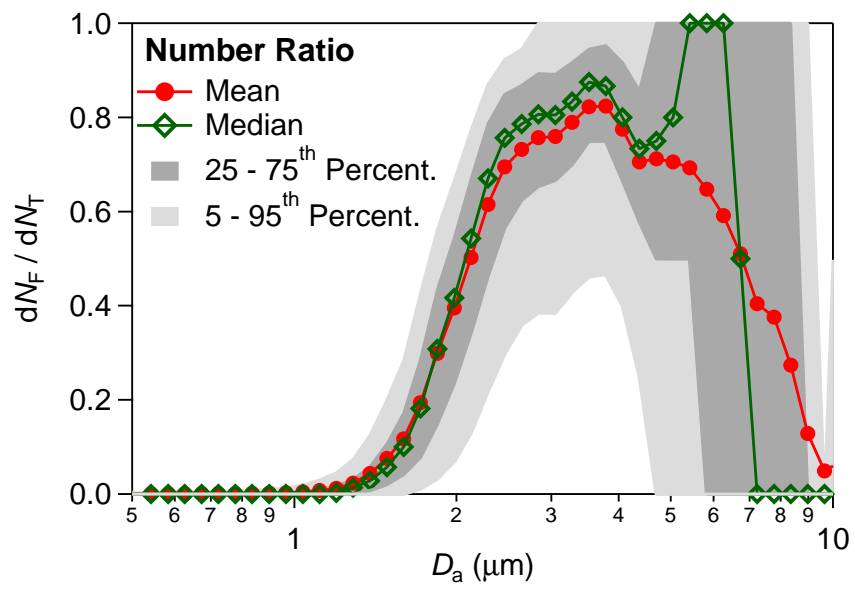

Fig. 3. Average size distribution of FBAP to total ratio for the measurement campaign $\left(\mathrm{d} N_{\mathrm{F}} / \mathrm{d} N_{\mathrm{T}}=\mathrm{d} M_{\mathrm{F}} / \mathrm{d} M_{\mathrm{T}}\right)$.

al., 2010; Schneider et al., 2011). The difference between the mean and median values of $\mathrm{d} N_{\mathrm{F}} / \mathrm{d} N_{\mathrm{T}}$ at particle diameters $>6 \mu \mathrm{m}$ highlights the low particle numbers at these sizes.

The campaign median FBAP number concentration was $0.073 \times 10^{6} \mathrm{~m}^{-3}$ (24\% of the total coarse aerosol), and the corresponding FBAP mass concentration was $0.72 \mu \mathrm{g} \mathrm{m}^{-3}$ (46\%) (Fig. 4 and Table 1). Microscopy analysis revealed that the remaining non-fluorescent aerosol was comprised primarily of mineral dust, non-fluorescent biological aerosol, and inorganic salts particles, listed in order of relative concentration. As means of perspective, the FBAP concentration values here can be compared to the ranges reported from a sampling of previous studies. For example, Matthias-Maser and Jaenicke (1995) reported a PBAP number concentration of $1.9 \times 10^{6} \mathrm{~m}^{-3}$ corresponding to $\sim 30 \%$ of the total particles $(>0.2 \mu \mathrm{m})$ whereas Huffman et al. (2010) reported $0.03 \times 10^{6} \mathrm{~m}^{-3}(\sim 4 \%)$ of coarse FBAP $(>1.0 \mu \mathrm{m})$, both sets of observations in the semi-urban setting of Mainz, Germany. A follow-up study for three geographically different sampling sites by Matthias-Maser and Jaenicke (2000) suggested that up to $25 \%$ of particles were PBAP. A semiurban site in Mainz at $3.1 \times 10^{6} \mathrm{~m}^{-3}(19.5 \%)$ had the highest concentration of the three sites, while a marine site on the Atlantic Ocean $(16.7 \%)$ and a remote continental site at Lake Baikal, Russia (19.5\%) each had particle number concentrations of $0.6 \times 10^{6} \mathrm{~m}^{-3}$. Artaxo et al. (1990) indicated that $55-95 \%$ of Amazon particle mass concentration $(>2 \mu \mathrm{m})$ was biogenic and possibly composed of a diverse set of PBAP, as observed by microscopic analysis of single particles. More recently Gabey et al. (2010) operated a wide-issue bioaerosol sensor (WIBS) and observed $\sim 0.15 \times 10^{6} \mathrm{~m}^{-3}$ of FBAP $(>0.8 \mu \mathrm{m})$ in a Borneo rainforest understory, corresponding to $\sim 28 \%$ of the aerosol, with up to $55 \%$ of the coarse aerosol above the canopy considered as FBAP. 

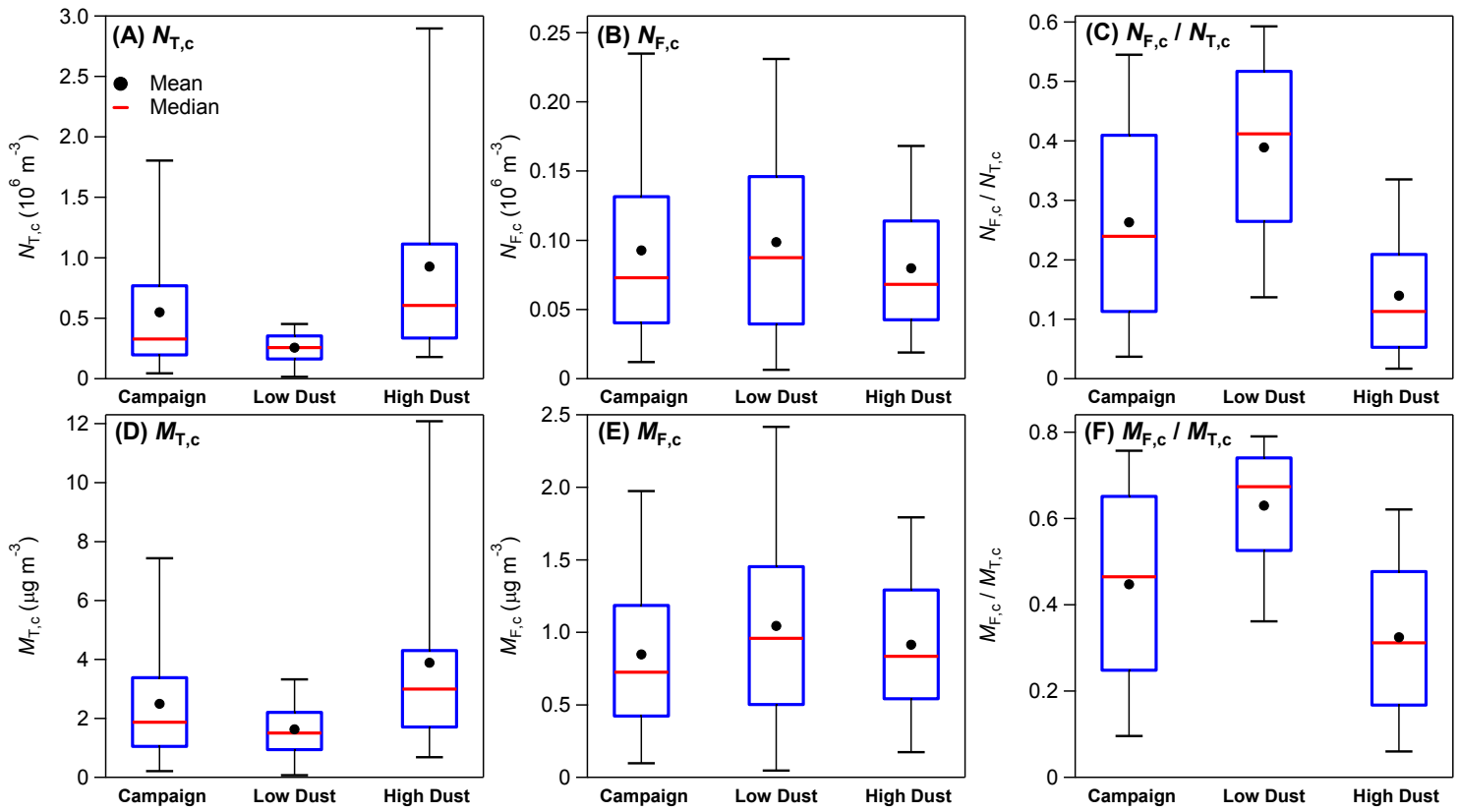

Fig. 4. Statistical distribution of integrated coarse FBAP and total number and unit-normalized mass concentrations (1-20 $\mu \mathrm{m})$ for each of three periods: entire campaign, low dust focus period, high dust focus period. (A) $N_{\mathrm{T}, \mathrm{c}}$, (B) $N_{\mathrm{F}, \mathrm{c}}$, (C) $N_{\mathrm{F}, \mathrm{c}} / N_{\mathrm{T}, \mathrm{c}}$, (D) $M_{\mathrm{T}, \mathrm{c}}$, (E) $M_{\mathrm{F}, \mathrm{c}}$, (F) $M_{\mathrm{F}, \mathrm{c}} / M_{\mathrm{T}, \mathrm{c}}$.

Table 1. Integrated number and unit-normalized mass concentrations of coarse FBAP and total particles (1-20 $\mu \mathrm{m})$. Arithmetic mean and median values shown for: Period 1 (2-19 February 2008), Period 2 (4-15 March 2008), High Dust focus period (2867 min average), Low Dust focus period (5608 min average), and entire campaign.

\begin{tabular}{|c|c|c|c|c|c|c|}
\hline \multicolumn{2}{|c|}{ Number } & \multirow{2}{*}{$\begin{array}{l}\text { Period 1: } \\
\text { 2-19 Feb } \\
0.78\end{array}$} & \multirow{2}{*}{$\begin{array}{l}\text { Period 2: } \\
\text { 4-15 Mar } \\
0.28\end{array}$} & \multirow{2}{*}{$\begin{array}{l}\text { High Dust } \\
\text { Focus Period }\end{array}$} & \multirow{2}{*}{$\begin{array}{l}\begin{array}{l}\text { Low Dust } \\
\text { Focus Period }\end{array} \\
0.26\end{array}$} & \multirow{2}{*}{$\begin{array}{l}\text { Campaign } \\
0.55\end{array}$} \\
\hline$N_{\mathrm{T}, \mathrm{c}}\left(\mathrm{m}^{-3}\right)$ & Mean & & & & & \\
\hline$\times 10^{6}$ & Median & 0.64 & 0.25 & 0.61 & 0.26 & 0.33 \\
\hline$N_{\mathrm{F}, \mathrm{c}}\left(\mathrm{m}^{-3}\right)$ & Mean & 0.097 & 0.088 & 0.080 & 0.099 & 0.093 \\
\hline$\times 10^{6}$ & Median & 0.078 & 0.068 & 0.068 & 0.087 & 0.073 \\
\hline \multirow{2}{*}{$\begin{array}{l}N_{\mathrm{F}, \mathrm{c}} / N_{\mathrm{T}, \mathrm{c}} \\
(\%)\end{array}$} & Mean & 18.7 & 35.1 & 14.0 & 38.9 & 26.3 \\
\hline & Median & 14.3 & 36.4 & 11.3 & 41.1 & 24.0 \\
\hline \multicolumn{2}{|c|}{$\begin{array}{c}\text { Mass } \\
\text { (Unit-Norm.) }\end{array}$} & $\begin{array}{l}\text { Period 1: } \\
2-19 \text { Feb }\end{array}$ & $\begin{array}{l}\text { Period 2: } \\
\text { 4-15 Mar }\end{array}$ & $\begin{array}{l}\text { High Dust } \\
\text { Focus Period }\end{array}$ & $\begin{array}{l}\text { Low Dust } \\
\text { Focus Period }\end{array}$ & Campaign \\
\hline \multirow{2}{*}{$\begin{array}{l}M_{\mathrm{T}, \mathrm{c}} \\
\left(\mu \mathrm{g} \mathrm{m}^{-3}\right)\end{array}$} & Mean & 3.25 & 1.63 & 3.89 & 1.63 & 2.49 \\
\hline & Median & 2.62 & 1.46 & 3.00 & 1.50 & 1.87 \\
\hline \multirow{2}{*}{$\begin{array}{l}M_{\mathrm{F}, \mathrm{c}} \\
\left(\mu \mathrm{g} \mathrm{m}^{-3}\right)\end{array}$} & Mean & 0.77 & 0.94 & 0.92 & 1.05 & 0.85 \\
\hline & Median & 0.67 & 0.81 & 0.83 & 0.96 & 0.72 \\
\hline \multirow{2}{*}{$\begin{array}{l}M_{\mathrm{F}, \mathrm{c}} / M_{\mathrm{T}, \mathrm{c}} \\
(\%)\end{array}$} & Mean & 31.8 & 59.6 & 32.5 & 63.0 & 44.7 \\
\hline & Median & 28.1 & 63.3 & 31.1 & 67.4 & 46.5 \\
\hline
\end{tabular}



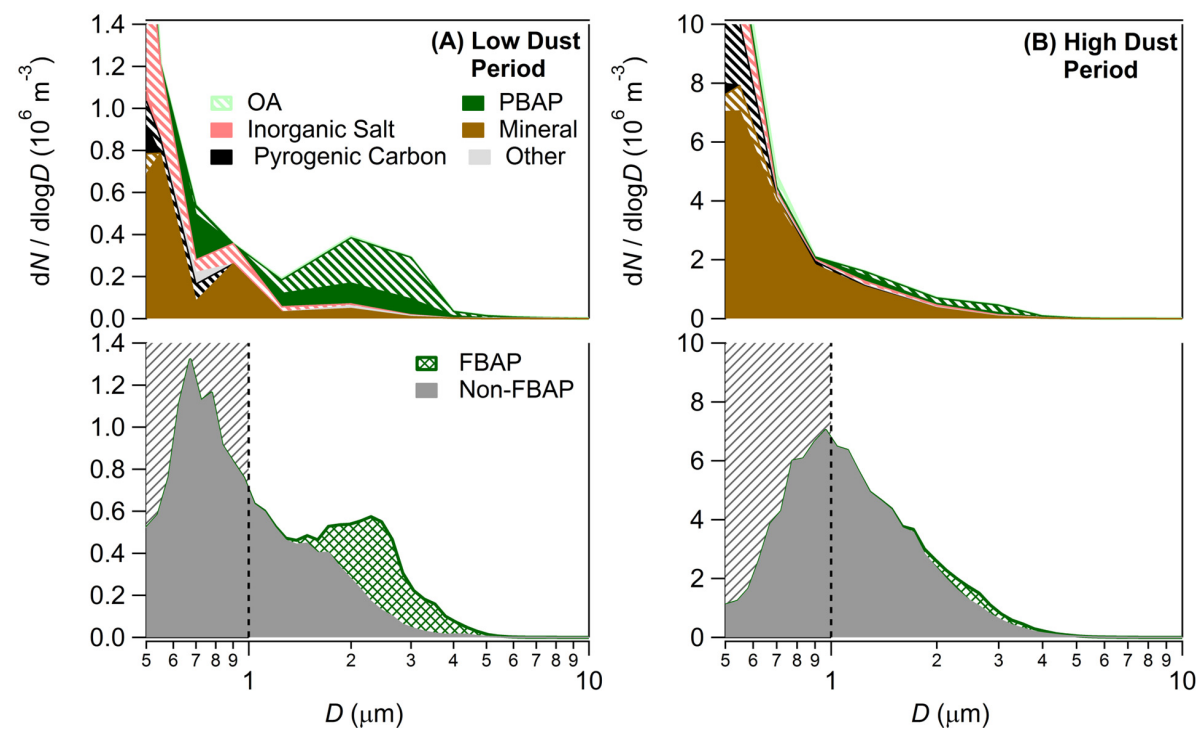

Fig. 5. Comparison of particle size distributions acquired from counting particles on filters using SEM (top panels) and in real-time from UVAPS (bottom panels). Colored areas are stacked in each case such that top line reflects the total concentration from each analysis technique. Upper panels: regions of solid color indicate uncoated particles, diagonal bars indicate particles coated with organic material. (A) Low Dust period (Average of sample numbers M04, M08, M12; 5608 min total), (B) High Dust period (Average of sample numbers M07, M30; 3867 min total). Size distribution from each analysis plotted with respect to its own method of particle size determination. Upper SEM panels shown versus physical diameter $\left(D_{\mathrm{p}}\right)$, as defined by visual determination through microscopy. Lower UV-APS panels shown versus aerodynamic diameter $\left(D_{\mathrm{a}}\right)$, operationally defined as the size a particle acts in a flowing stream of air as if it were condensed into a sphere of unit density (DeCarlo et al., 2004).

The same group reported observations from an urban site in Manchester, England where a range of $0.03-0.1 \times 10^{6} \mathrm{~m}^{-3}$ FBAP was observed, depending on the combination of excitation and emission wavelengths used for FBAP determination (Gabey et al., 2011). The absolute values of PBAP concentration reported by these studies differ by two orders of magnitude in number and by one order of magnitude in the fraction of biological particles to the total. This range of values highlights the variability of PBAP concentrations both in different environments and using different methods, but also underscores that bioaerosol particles are indeed important to the coarse-mode burden of the atmosphere in each environment monitored (Després et al., 2012). The reports by the Jaenicke group count PBAP directly using optical microscopy insensitive to secondary organic material and soot whereas the WIBS and UV-APS only detect biological aerosol by on-line auto-fluorescence and at different wavelengths of excitation and emission for the two instruments. The difference in particle size ranges sampled between the studies can account for most of the large differences in absolute number concentrations, especially at lower particle sizes.

\subsection{Focus period comparison}

Averages for total number and mass concentrations during each of three periods (High Dust focus, Low Dust focus, and Entire Campaign) are shown in Fig. 4. Each of the focus peri- ods represents an average of short time periods ( 48 and $90 \mathrm{~h}$, respectively), while the campaign average takes all available data from Fig. 1 into account. The total particle number and mass (Fig. 4a, d) decrease significantly from high to low dust periods, while the FBAP number and mass show relatively stable mean and median concentration values (Fig. $4 \mathrm{~b}, \mathrm{e}$ ). Thus, the primary biological particle concentration exhibited a consistent daily pattern, and the capability to detect these particles in real-time by auto-fluorescence at $355 \mathrm{~nm}$ excitation was not heavily influenced by large fluctuations in total particle concentration. The $N_{\mathrm{F}, \mathrm{c}} / N_{\mathrm{T}, \mathrm{c}}$ ratio represents a convolution of total particle and FBAP trends; the relative fractions of FBAP number and mass were thus highest during the later low dust period.

Figure 5a and $\mathrm{b}$ highlight results of both SEM and UVAPS analyses for the Low and High Dust focus periods, respectively. A first-glance observation of these plots shows that the general trend of the numbers from SEM (upper panels) and UV-APS (lower panels) are broadly similar. The size distribution of the total aerosol for both analysis methods peaks at small sizes during the low focus period, drops quickly to a local minimum $\sim 1.3 \mu \mathrm{m}$, and then rises to a secondary maximum at $\sim 2-2.3 \mu \mathrm{m}$. Adjusting $D_{\mathrm{a}}$ of the lower panels to $D_{\mathrm{p}}$ would shift UV-APS size distributions left (if $\rho>1$ ), proportional to the square root of the physical density of the particles $(\rho)$. Density-related shifts thus partially explain the size shift between the two panels most apparent 
during the High Dust period. Particle density was not measured for these particles, however, and varies as a function of particle type. For these reasons we present the axes unaltered, thus utilizing fewer uncertain assumptions. Additionally, Reponen et al. (2001) observed for several fungal spores types that $D_{\text {a }}$ can be shifted significantly $(\times 0.45-1.5)$ with respect to $D_{\mathrm{p}}$ for individual particle types and conclude that quantitative size comparisons between bioaerosol measurement techniques is more uncertain than often assumed.

A second observation is that the relative placement and proportion of PBAP from the SEM analysis are very similar to that of FBAP from the UV-APS. During each of the two periods shown, the largest fraction of the supermicron UVAPS number is non-fluorescent aerosol, especially at particle diameters $<2 \mu \mathrm{m}$, whereas fluorescent particles are present between 1.8-4 $\mu \mathrm{m}$. The FBAP concentration during the High Dust focus period may appear minimal as compared with the Low Dust focus period to the left. However, it is important to note that the FBAP concentration is consistent during both periods (within $20 \%$ ) and that the apparent reduction in FBAP is a visual effect of the significantly increased non-fluorescent particle concentration and increased vertical scale.

Several of the filter samples were also subjected to a staining procedure used to highlight fungal spores and material. As mentioned previously, only sample M12 $(\sim 24 \mathrm{~h}$ sampling time, 12 March) was successfully stained on both fine and course filters, and the results of this sample are compared in Fig. 6 to UV-APS and SEM-analyzed samples acquired over the same time period. The particles from sample M12 counted as fungal are shown in Fig. 6a. Most important to observe is that the distributions derived from three different analyses appear qualitatively similar. Specifically, the fungal stain plot and PBAP fraction the SEM analysis both exhibit a single dominant peak centered at $2 \mu \mathrm{m}$, with similar slopes on either side of the peak. Samples M04 and M08, each successfully stain-processed with only one of the two parts of the filter stack, are also useful for comparison, showing trends consistent with those discussed here for sample M12 (Fig. S1). The consistency in average particle distribution between analyses from fungal staining, SEM imaging, and on-line fluorescence detection highlights that each technique is able to sample and analyze the same biological material, despite radically different analytical methods. Further, the similarity in size between the fungal stain and SEM distributions above $1 \mu \mathrm{m}$ suggests that PBAP as determined by SEM analysis is likely to be dominated by fungal spores. The observations here agree qualitatively with previous studies (Graham et al., 2003a; Elbert et al., unpublished results) that coarse-mode particles in the Amazonian basin are dominated by fungal spores and yeasts and that PBAP in many environments exhibit fungal spore peaks in the range of $\sim 1-4 \mu \mathrm{m}$ (e.g., Lin and $\mathrm{Li}, 1996$; Burch and Levetin, 2002; Graham et al., 2003a). Quantitatively, however, the particles positively identified during this $24-\mathrm{h}$ pe-

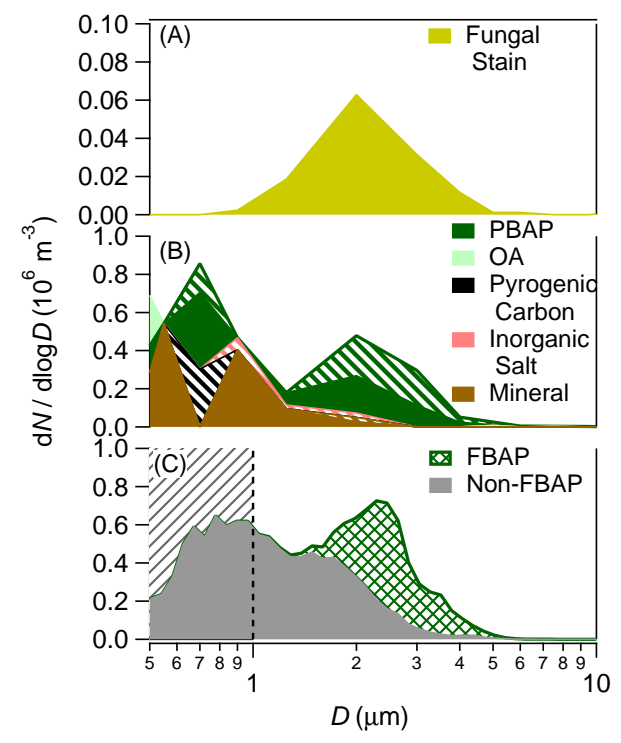

Fig. 6. Comparison of particle size distributions from three techniques: (A) lactophenol blue fungal (chitin) stain, (B) counts from SEM analysis, (C) UV-APS. Colored areas are stacked plots. For middle panel, regions of solid color indicate uncoated particles, diagonal bars indicate particles coated with organic material.

riod using the chitin stain comprise only $\sim 18 \%$ of the total PBAP observed in the supermicron mode. This discrepancy could indicate the presence of spores of fungus-like species with cell walls comprised of skeletons not made of chitin, such as many yeasts, Cryptomycota, and Peronosporomycota (formerly Oomycota) (Bartnicki-Garcia, 1968; Helbert et al., 1997; Petersen and Rosendahl, 2000; Jones et al., 2011). Another possibility is that the remaining fraction is biological (e.g. plant spores, bacterial agglomerates, cell fragments), but non-fungal in nature, as has been reported previously. For example, Wang et al. (2008) showed using an Andersen sixstage impactor that airborne bacteria in both rural and urban air samples from central Taiwan were collected most efficiently at aerodynamic sizes between 1.1-3.3 $\mu \mathrm{m}$. And, while individual pollen particles are almost always larger than the nominal upper cut-off of the inlet as constructed for this study $(\sim 7 \mu \mathrm{m})$, cytoplasmic fragments from ruptured pollen cells can be $\sim 0.05-2 \mu \mathrm{m}$ in size (Taylor et al., 2004; Miguel et al., 2006; Pöhlker et al., 2012c). Mixed organic and inorganic coatings found on $\sim 40 \%$ of the PBAP (Sect. 3.5) may also inhibit staining and lead to systematic underestimates.

Figure $6 \mathrm{~b}$ also shows an increased number of PBAP between $0.5-1.0 \mu \mathrm{m}$, but not positively identified by the lactophenol blue stain or as fluorescent by the UV-APS. This observation indicates the presence of biological material at smaller sizes and may also indicate poorer fluorescence sensitivity for smaller biological particles detected by the UVAPS. Artaxo and Hansson (1995) observed a fine mode biogenic component to aerosol sampled from the Amazon, suggesting that it was evenly vertically spread throughout the 


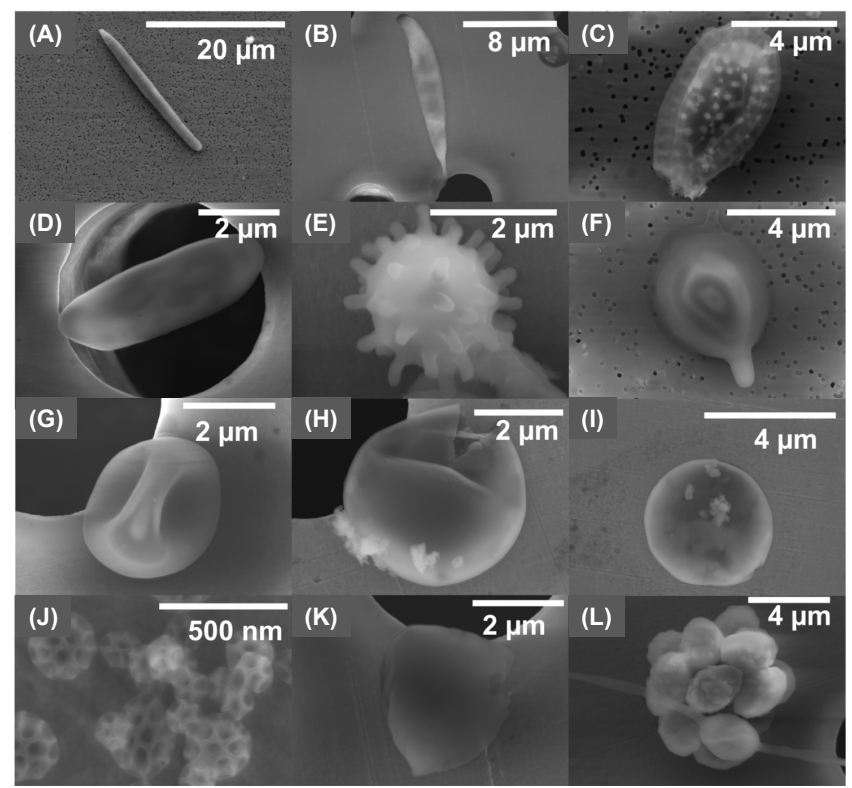

Fig. 7. Scanning electron micrographs showing example PBAP images from AMAZE-08 campaign. Scale bar shown in each panel.

canopy. This mode may be composed of individual bacterial cells, non-chitin-containing spores, brochosomes, pollen fragments, droplets of sugar solution ejected by microorganisms, or other uncategorized bioparticles.

Figure 7 shows a representation of biological particle types seen regularly by SEM analysis, similar to summaries presented previously (Wittmaack et al., 2005; Coz et al., 2010; Martin et al., 2010b). These images are not meant to be a quantitative summary, but represent particle types consistently observed. The selection of particles shows a variety of particles that are likely fungal spores (Figs. 7a-i). Figure $7 \mathrm{~b}$, in particular, has the appearance of particles suggested by Wittmaack et al. (2005) to be fungal spores like Cladosporium, and Fig. 7e appears to be a spinose basidiospore such as one of the Agaricales-order mushroom like Inocybe calospora (Avis et al., 2006). Figure 71 shows an intriguing image of a particle type not seen often during the study, which may represent an agglomeration of basidiospores or possibly large bacterial cells. This highlights how some biological particles can be individually small, but may be detected at much larger sizes. Figure $7 \mathrm{j}$ shows a collection of brochosomes. In addition to the diverse supermicron particle types represented in Fig. 7, submicron particles, often round in morphology, that appeared biological in origin were often routinely seen during SEM analysis.

\subsection{Diurnal patterns}

\subsubsection{Particle observations}

As discussed above, supermicron concentrations and size distributions of total particles over the measurement period were typically observed to be more episodic and less regular than FBAP. Another important distinction is that FBAP concentrations exhibit a strong diurnal (defined as daily or 24-h) cycle, whereas average total particle concentrations are more consistent throughout the day. This can be seen by the regular pattern in Fig. $1 \mathrm{~b}$ and $\mathrm{d}$ and is even more apparent when plotted as median values of FBAP number or mass versus time of day in Fig. 8. Supplement Fig. S2 shows the same plot averaged over the entire campaign and shows qualitatively similar trends, but with greater noise and higher total particle concentrations. $N_{\mathrm{F}, \mathrm{c}}$ is clearly highest during night-time hours, starts dropping just before sunrise, and rises again just after sunset. Times are reported in LT and local sunrise, solar noon, and sunset occurred on average at approximately 06:07, 12:12, and 18:17, respectively. $N_{\mathrm{T}, \mathrm{c}}$ shows a flatter diurnal profile, with relatively consistent morning concentration followed by slightly lower afternoon concentrations. $M_{\mathrm{T}, \mathrm{c}}$ also shows little diurnal trend, though there is a slightly larger difference between early morning and evening than was the case for $N_{\mathrm{T}, \mathrm{c}}$. The diurnal $M_{\mathrm{T}, \mathrm{c}}$ distributions, however, clearly show the large mass fraction that fluorescent biological particles contribute to the total. The number-weighted image of total particles (Fig. 8a) shows only slight presence of fluorescent particle concentrations at $2-3 \mu \mathrm{m}$ during the early morning hours, while the massweighted image (Fig. 8c) shows a much stronger bimodal distribution that very clearly tracks the corresponding FBAP mass plot.

\subsubsection{Non-fluorescence of certain biological particles}

The diurnally resolved size distribution of FBAP shows that the majority of the $N_{\mathrm{F}, \mathrm{c}}$ appears within a relatively narrow peak centered at $\sim 2.4 \mu \mathrm{m}$ for each hour of the day and that the total particle distribution has more contribution from smaller sizes. These trends are more explicitly obvious in Fig. 9, in which non-fluorescent (gray) and fluorescent (green) particle concentrations are shown stacked on top of one another. Non-fluorescent particles have a generally negative slope from $\sim 0.7 \mu \mathrm{m}$ to $\sim 4 \mu \mathrm{m}$ during each 4 $\mathrm{h}$ average. The total particle concentration peaks in the late morning (08:00-12:00), decreases throughout the rest of the day and night, and then sharply increases again after sunrise. The FBAP concentration, in contrast, is lowest in the late morning, rises slowly until the early morning (00:00-04:00) and then slowly decreases again. From 08:00-16:00 the nonfluorescent distributions are smooth and exhibit monotonically decreasing slopes. Beginning in the 16:00-20:00 block, however, a small secondary peak appears at $\sim 1.6 \mu \mathrm{m}$, just as the FBAP peak start to grow. As time goes on, and as the FBAP grows more significant, the secondary peak in the non-fluorescent distribution grows with it. The correlation of the dominant fluorescent biological particle peak with the secondary non-fluorescent peak suggests that the latter also comes from related biological processes. This seems to 


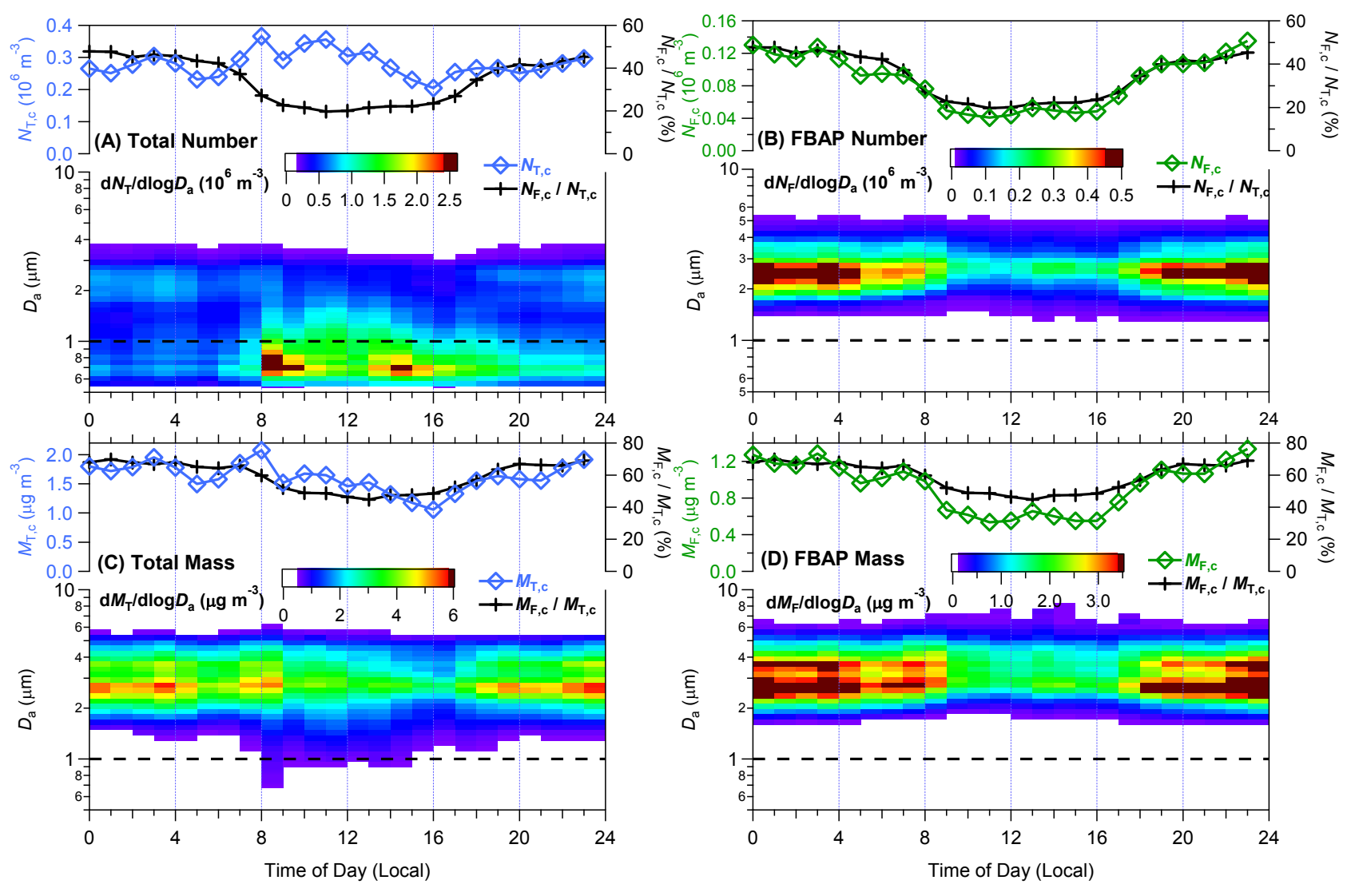

Fig. 8. Diurnal cycles of mean FBAP and total particle concentrations during low dust period (4-15 March 2008). Number and unitnormalized mass integrated 1-20 $\mu \mathrm{m}$, so peaks at small particle size not included. (A) total number, (B) FBAP number, (C) total mass, (D) FBAP mass. Black line consistent in panels of same row: (A) and (B) show relative number contribution, and (C) and (D) show relative mass contribution from fluorescent biological particles. Time of day shown as local time (LT); mass is unit-normalized. The second half of the campaign (nominally the lower dust period) was used for averaging the diurnal values to more clearly highlight the trends of bioaerosol emissions from the forest alone. Sunrise ca. 12:17, solar noon ca. 12:12, sunset ca. 18:17.

further indicate that, while the fluorescent signal used to determine FBAP concentration captures most of these particles, at certain times of the day and when the FBAP concentrations are greatest, some fraction of biological material, especially particles of small size, may be below the fluorescence detection limit of the UV-APS. The source and identity of these particles is difficult to ascertain from UV-APS measurements alone, but we suggest the particles are likely to be fungal spores or bacteria emitted regularly every night. Gabey et al. (2010) also reported a mode of non-fluorescent particles associated with the FBAP peaks, suggesting small or weakly fluorescent particles may not be detected as biological by real-time aerosol LIF instrumentation, whether excited in the $\sim 350 \mathrm{~nm}$ or $\sim 260-280 \mathrm{~nm}$ regions.

This point is highlighted in more detail in Fig. 10 by analyzing two periods on 12 March as a case-study. FBAP concentrations from $\sim 11-13$ March were very stable and exhibited a reproducible diurnal pattern. From those days we chose an afternoon period from 12:00-16:00 on 12 March along with the immediately following night period from 20:00-
24:00 for comparison. As was true for the diurnal averages of the longer period of the campaign, the afternoon period shown in Fig. 10a exhibits a relatively consistent negative slope for non-fluorescent particles, with a single FBAP peak at $2.5 \mu \mathrm{m}$. For the early morning period, however, the non-fluorescent particle distribution had a second peak at $\sim 1.7 \mu \mathrm{m}$ with a FBAP peak at $\sim 2.5 \mu \mathrm{m}$ and higher overall FBAP concentration. To highlight the difference between the afternoon and night periods of Fig. 10, multi-peak fitting analysis was performed on each of the distributions. In each of the 4-hour periods a three-peak fit of the FBAP distribution retrieved peaks at similar particle sizes and local maxima; the largest peak occurs at $\sim 2.5 \mu \mathrm{m}$, with smaller peaks of relatively equal height during each period at 1.9-2.2 and 3.4$3.5 \mu \mathrm{m}$, respectively. The consistent size distribution across these periods suggests that the FBAP detected during the afternoon and night periods chosen here were biological material of possibly common origin. The non-fluorescent particle distributions, however, have strongly contrasting behavior. A two-peak fit of the non-fluorescent particle distribution 


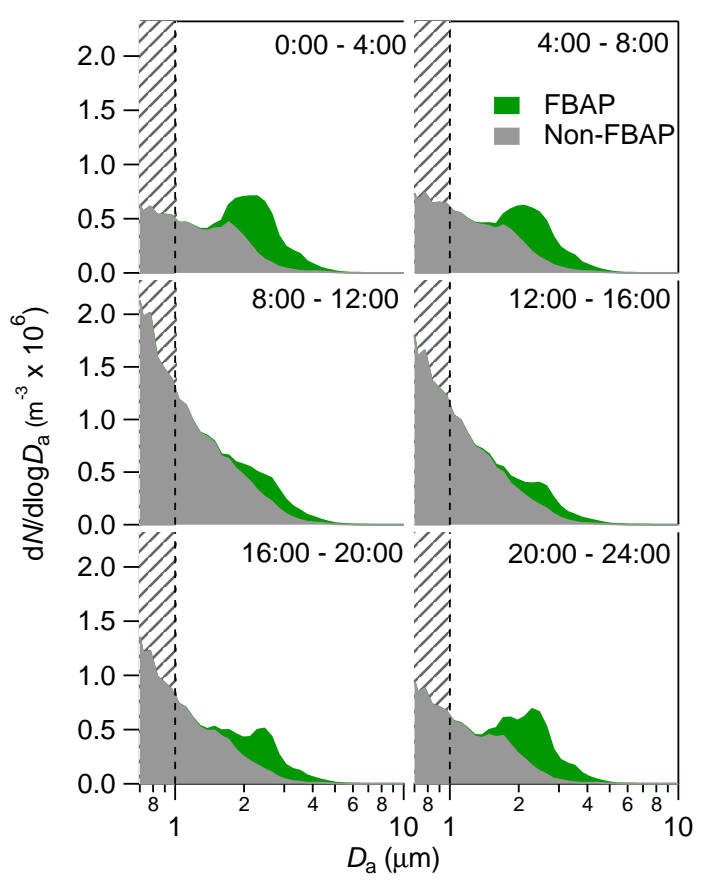

Fig. 9. Particle size distributions from UV-APS plotted as a function of time of day in four-hour blocks for Period 2 (4-15 March). FBAP stacked on top of non-FBAP in each panel.

of the afternoon data indicates a large, broad peak centered at $\sim 0.7 \mu \mathrm{m}$ and a relatively broad, but very low peak centered at $2.19 \mu \mathrm{m}$. A three-peak fit of the non-fluorescent particle distribution from the night data retrieves two peaks as very similar to those retrieved for the afternoon data: a dominant peak centered at $\sim 0.7 \mu \mathrm{m}$ and another relatively broad peak at $1.89 \mu \mathrm{m}$. In contrast to the afternoon period, however, a third and relatively narrow peak at $\sim 1.65 \mu \mathrm{m}$ is necessary to reconstruct the overall shape of the non-fluorescent curve successfully.

While choosing a larger number of peaks for automatic fitting would have resulted in better overall fits, the exercise was designed to determine a small number of peaks that could reasonably reflect the dominant modes within the short periods of data. The results of this multi-peak fitting analysis emphasize that, at least over the range of periods chosen for analysis here, the biological material being emitted by the forest was relatively stable in particle size and therefore likely so in source. The multi-peak fitting analysis also highlights that, while the UV-APS is able to detect FBAP efficiently during certain periods of the day, a certain fraction of biological material escapes characterization using the UVAPS with $355 \mathrm{~nm}$ excitation.

\subsubsection{Sources of diurnal patterns}

The diurnal FBAP patterns observed are likely caused by a combination of two dominant mechanisms, as also proposed and discussed previously (e.g., Graham et al., 2003a; Rissler et al., 2006). First, emission and dispersal of biological particles is strongly tied to environmental variables such as solar radiation, temperature, and moisture, each of which has strong diurnal cycles. Second, particles emitted during nighttime hours when the atmospheric boundary layer is shallow decrease in concentration as the sun rises, turbulence increases, and layer thickness increases, and the layer shifts higher (e.g., Garland et al., 2009). Commenting on measurements in Borneo, Whitehead et al. (2010) suggested that the break-up of the atmospheric boundary layer was the reason for the daily morning decrease in FBAP concentrations and a dominant reason for the observed daily pattern in general. Graham et al. (2003a) also suggest the nocturnal increase in coarse PBAP to be the result of the shallow nighttime boundary layer, but suggest that nocturnal sporulation may have also contributed.

Detailed diurnal cycles of biological aerosol particles, many of which closely resemble observations discussed here, have been reported previously. Such studies date at least as far back as measurements by Hirst (1953), who also observed daily increases in fungal spores and pollen coinciding with environmental variables. Much more recently and utilizing on-line fluorescence detection Gabey et al. (2010) reported FBAP in Borneo peaking at night and again in the midafternoon, with stronger trends observed below the canopy than above, suggesting spores were responsible for observations (Stanley et al., 2011). Tong and Lighthart (1999) reported a diurnal cycle of total atmospheric bacteria sampled with a wet-wall sampler, which increased steadily through the day, peaked at night, and was lowest in the early morning; however, measurements in this study were restricted to 05:00-21:00 LT. Graham et al. (2003a, b) observed a nocturnal increase in the $2-10 \mu \mathrm{m}$ particle fraction in the Amazon and suggested that it was likely related to PBAP. They further suggested that coarse particles increased by as much as $90 \%$ at night and were dominated by fungal spores (as determined by light microscopy). The regular daily pattern of airborne fungal spore concentrations has been observed especially often. For example, Gilbert (2005) sampled airborne fungal spores in a Queensland, Australia rainforest during the early wet season and saw distinct daily patterns that closely match qualitative observations reported here. That report states that observed spore concentrations increase "sharply around sunset, remaining high throughout the night, and then decline sharply shortly after sunrise". Other groups have reported seeing increases in airborne fungal spore concentrations at night, varying by season and sampling location (e.g., De Groot, 1968; Elbert et al., 2007; Abdel-Hameed et al., 2009). Factors related to emission of PBAP, whether bacteria, fungal spore, or otherwise, are strongly dependent on species, however (e.g., Gilbert, 2005), and many studies have focused on specific phyla or genera. De Groot (1968) report the diurnal behavior of several spore types, noting that most were observed to peak nocturnally, with the exception of Cladosporium conidia which consistently peaked at 

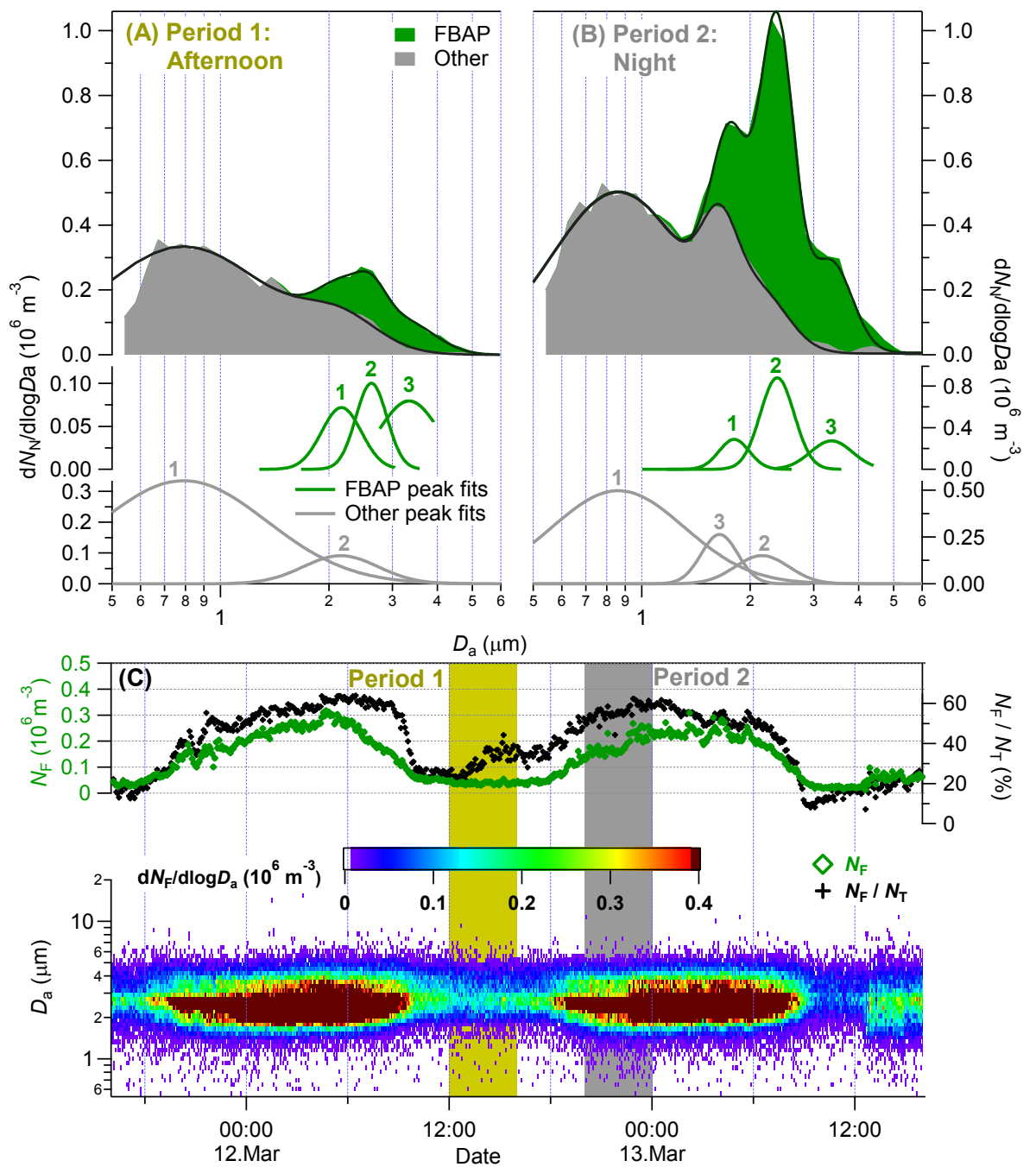

Fig. 10. (A) and (B) Particle size distributions of fluorescent and non-fluorescent aerosol for two individual four-hour blocks on 12 March. Top panels show stacked size distributions from UV-APS. Individual traces below show peaks fit to FBAP (green) and non-FBAP (gray) with number label of each peak. Sum of all peak fits shown in top panel is dark lines. (C) Size distribution, integrated number, and ratio of FBAP/total for each 5-min data point. Yellow bar indicates Period 1 (Afternoon: 12:00-16:00), gray bar indicates Period 2 (Evening: 20:00-24:00).

approximately midday and were least concentrated at night. Pady et al. (1969), however, observed a clear diurnal cycle of Cladosporium spores, peaking early in the morning after sunrise (07:00-08:00 LT), but varying in time of appearance over a $\sim 12$-h window. Rockett and Kramer (1974) reported a night-time $(02: 00 \mathrm{LT})$ increase of basidiospores in several US cities, with additional weak evidence of a second evening emission period (21:00 LT) in some species. Many reports have since agreed with these observations by suggesting that basidiospore concentrations increase with relative humidity $(\mathrm{RH})$ and often peak in the early morning (Hirst, 1953; Adams et al., 1968; Burge, 1986; Calderon et al., 1995; Troutt and Levetin, 2001). Troutt and Levetin (2001) followed this to say that not only do basidiospores have a clear diurnal rhythm, peaking at 04:00-06:00 LT, but that ascospores showed none. Paulitz (1996), in contrast, reported that Ascomycota did show a diurnal pattern, with a peak in concentrations just before midnight and related to RH and leaf wetness. Spore color has also often been useful for determination of identity (Adams et al., 1968; Troutt and Levetin, 2001), with average differences in opacity also showing diurnal differences (Hirst, 1953). Bell-Pedersen et al. (1996) summed up the differences between fungal species by stating that the time of fungal spore emission also suggests differences in spore identity: "In general, thin-walled spores that are sensitive to injury by light and desiccation or spores that require turgor pressure for release are liberated at night (nocturnal). Alternatively, thicker-walled ultravioletresistant, hydrophobic spores are usually released during the day (diurnal)." 

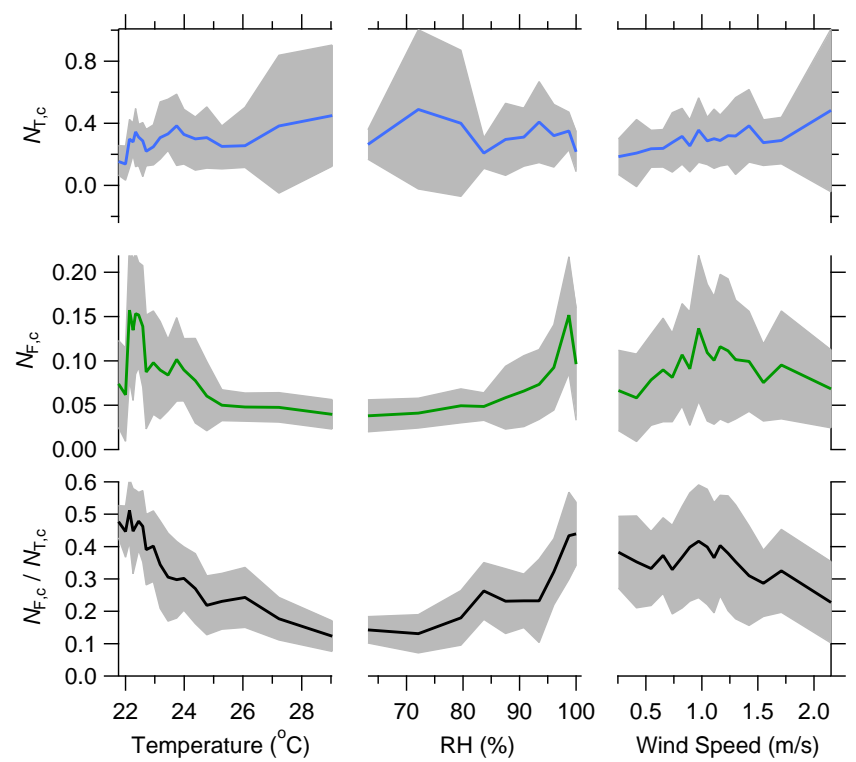

Fig. 11. Correlations of UV-APS particle number $\left(N_{\mathrm{T}, \mathrm{c}}, N_{\mathrm{F}, \mathrm{c}}\right.$, and $N_{\mathrm{F}, \mathrm{c}} / N_{\mathrm{T}, \mathrm{c}}$ ) with meteorological parameters (temperature, relative humidity, and wind speed). Colored line indicates campaign mean value and gray shading indicates plus and minus one standard deviation.

\subsection{Meteorological correlations}

The results of the UV-APS analysis from AMAZE-08 were plotted with respect to meteorological parameters such as ambient temperature, relative humidity, wind speed, and down-welling solar radiation measured during the second half of AMAZE-08 to investigate factors related to possible bioaerosol source mechanisms. Correlations for different classes of particles with meteorological parameters were weak, but did exist to varying degrees. Figure 11 shows correlations with temperature, $\mathrm{RH}$, and wind speed measured at the top of the measurement mast. Although $N_{\mathrm{T}, \mathrm{c}}$ has little trend with the meteorological parameters, $N_{\mathrm{F}, \mathrm{c}}$ and $N_{\mathrm{F}, \mathrm{c}} / N_{\mathrm{T}, \mathrm{c}}$ show more discernable patterns. $N_{\mathrm{F}, \mathrm{c}}$ and $N_{\mathrm{F}, \mathrm{c}} / N_{\mathrm{T}, \mathrm{c}}$ are both highest at lower temperature and higher RH. In general, $N_{\mathrm{T}, \mathrm{c}}$ increases and $N_{\mathrm{F}, \mathrm{c}} / N_{\mathrm{T}, \mathrm{c}}$ decreases with increasing wind speed, but $N_{\mathrm{F}, \mathrm{c}}$ shows little trend. This may indicate that wind speed alone is not a good marker for the release of the observed PBAP and that lower wind speed may actually increase emission of some spore types ( $\mathrm{Lin}$ and $\mathrm{Li}$, 2000; Troutt and Levetin, 2001; Jones and Harrison, 2004). The correlations shown are not surprising, but also do not necessarily imply causality. Because $N_{\mathrm{T}, \mathrm{c}}$ has a clear diurnal cycle, as do solar radiation, temperature, and RH (Fig. S3), a correlation is expected. It is unclear from these data if and how these environmental parameters may contribute to bioaerosol release mechanisms. Correlations with rain events were also performed. While heavy rain periods contributed significantly to aerosol (total particles and FBAP) wash-out, correlation of FBAP increase during or after rain events was not apparent, as was expected (e.g., McCartney and Lacey, 1990; Gottwald et al., 1997; Huffman et al., 2012; Prenni et al., 2012).

Jones and Harrison (2004) suggested that fungal spore release is dependent more so on changes in environmental variables than on their absolute values and that this may mask interpretation of meteorological and bioaerosol correlations. Delays of minutes to days after changes in critical environmental variables before bioaerosol emission may be present, and this further confounds simple analysis (e.g., Huber and Gillespie, 1992; Battarbee et al., 1997). Temperature, wind speed, and RH have all been shown to influence pollen release and concentrations (Miguel et al., 2006). Oliveira et al. (2009) suggested the existence of multiple spore types, where a first type exhibited negative correlations with temperature and positive correlations with RH and rainfall, while a second type showed exactly opposite trends. They further suggested that spores in phyla such as Cladosporium, Alternaria, and Epiccocum (included in their second group) tend to be most prevalent in warm, dry conditions while ascospores and basidiospores tend to be more common during cooler, humid conditions (also Troutt and Levetin, 2001; Burch and Levetin, 2002). Based on these comments one might expect that the observations reported here, i.e., FBAP increases late at night and correlates with decreasing temperature and increasing $\mathrm{RH}$, would more likely classify the observed FBAP in Oliveira's first type of spores. The correlations performed and statements written here, however, were intended only to allow us to formulate a rough hypothesis meant for the purpose of discussion and not as a developed theory. Comparisons with multi-month averages merely suggest rough possibilities that would need to be explored in much more detail, but this is beyond the scope of the present text.

\subsection{Organic particle coatings with inclusion of primary material}

As was previously discussed by Pöschl et al. (2010), we observed during the AMAZE-08 campaign that a large fraction of supermicron particles were coated with liquid organic material. Most mineral dust particles were observed to be uncoated by organic material. Biological and pyrogenic carbon particles, however, were often observed with coatings of organic or mixed organic/inorganic material of variable thickness. The dominance of secondary organic aerosol (SOA) in the submicron fraction in the Amazon region (e.g. Chen et al., 2009) suggests that secondary processes are plausible sources for the observed organic coatings due to agglomeration of uncoated supermicron particles with many smaller SOA droplets. It has also been observed that many submicron organic particles collected in the Amazon exhibit inclusion of salts from primary biological origin (Pöhlker et al., 2012b). Here we see that many primary biological particles 


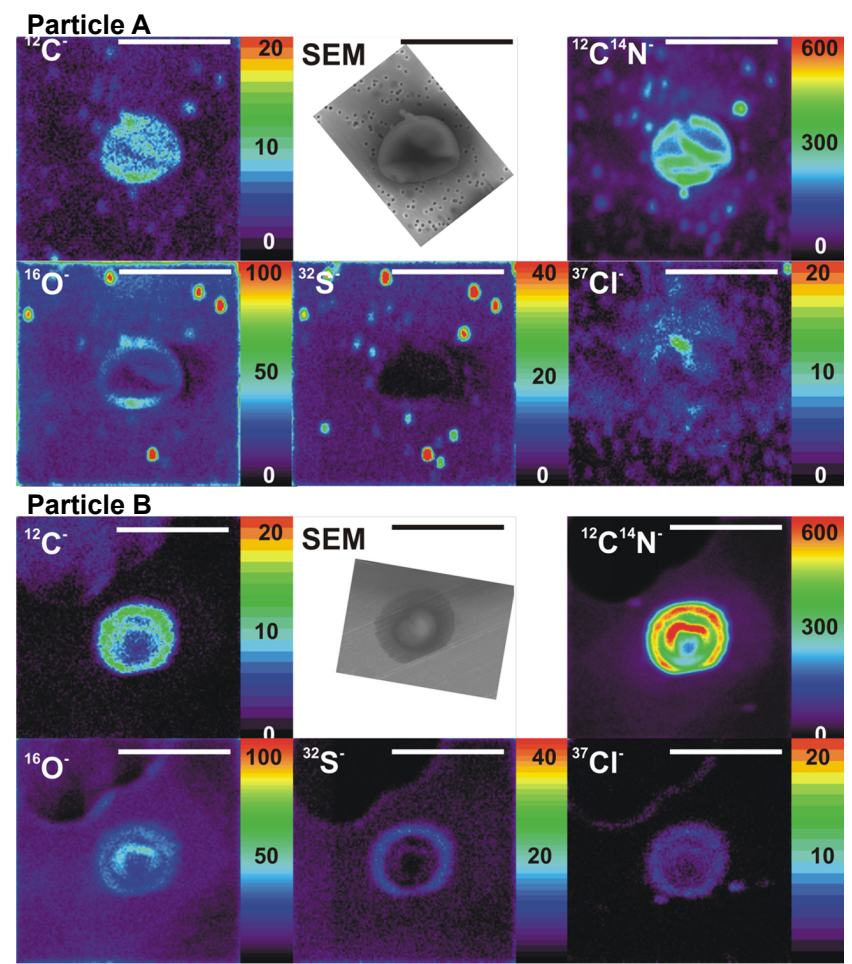

Fig. 12. SEM and NanoSIMS images of two example particles. Particle A (top two rows): uncoated PBAP. Particle B (bottom two rows): coated PBAP. Black and white image shows SEM micrograph of each particle. Colored images show map of particle, colored by intensity of concentration of respective elemental ions. Both particles collected during the period of low dust and biomass burning pollution. Units are arbitrary, but scaled the same between each pair of elements. Scale-bar is $5 \mu \mathrm{m}$ in length.

exhibited coatings of such liquid material. Figure 12 shows images from NanoSIMS analysis of two biological particles collected during the campaign. Particle A (Fig. 12, top rows) is an example of a PBAP present without liquid coating, and particle B (Fig. 12, bottom rows) is a typical example of a PBAP with thick $(\sim 1 \mu \mathrm{m})$ liquid coating. The NanoSIMS images show qualitatively similar concentrations of ${ }^{16} \mathrm{O}^{-}$ and ${ }^{12} \mathrm{C}^{-}$in the coated and uncoated PBAP. However, for the coated PBAP example the coating material is enriched in inorganic elements such as ${ }^{32} \mathrm{~S}^{-}$and ${ }^{37} \mathrm{Cl}^{-}$and strongly enriched in $\mathrm{N}^{-}$, ionized in the form of ${ }^{12} \mathrm{C}^{14} \mathrm{~N}^{-}$. The cations present in the coatings were analyzed using energy dispersive $\mathrm{x}$-ray spectroscopy, and $\mathrm{K}$ was found to dominate over $\mathrm{Na}$, especially during low dust periods. The presence of K, used as a tracer for active wet discharge of fungal spores (Elbert et al., 2007), in particular, suggests primary material in these coatings. Organic material enriched with nitrogen and chloride (Fig. 12) may also indicate electrolytes of biological origin, although chloride observed in Amazon aerosol can also be attributed to sea salt, especially in mixed mineral dust particles (e.g. Artaxo and Hansson, 1995), and nitrogen could arise from gaseous ammonia. Elbert et al. (2007) estimated the amount of organic material and electrolytes from spores of several species of fungi. The amount of material ejected with each spore is unlikely to form $1 \mu \mathrm{m}$ thick coatings on individual particles, and so Pöhlker et al. (2012b) argue the organic material is likely of secondary origin. We were not able to directly detect the mechanism of formation of the coating material observed during this study; was the mixed organicinorganic material co-ejected during active wet discharge of biological particles from their source (Pringle et al., 2005; Elbert et al., 2007), or did primary material help seed secondary organic aerosol formation, which then re-condensed onto the PBAP? Taken together, however, the presence of potassium, nitrogen, sulfur, and chloride in certain PBAP coatings suggests that the fluid layer contains at least inorganic, if not also organic, material from primary biological origin. By either of the two suggested mechanisms, PBAP coated in organic material rich in inorganic salt species are highly hygroscopic and could be very efficient as GCCN. This suggests that even large PBAP could influence the evolution of clouds and precipitation and, thus, could be important for the scientific understanding of the hydrological cycle, especially in vegetated regions where PBAP account for large fractions of supermicron particles. The presence of coatings on biological particles could provide natural fitness benefits for the species involved by helping to resist against major stresses of the atmosphere: UV radiation and atmospheric desiccation. Particle coatings could both help absorb UV radiation or change their reflective properties, thus protecting the viability of the cell inside (Attard et al., 2012). And whether of primary biological origin or condensed secondary material, coatings could provide the same benefit of encapsulating the PBAP as do natural extrapolysaccharides (EPS): helping to protect cells from death due to desiccation (Potts, 2001). If the coating is more hygroscopic or ice active than the native cell wall material it could provide a fitness benefit for the species by preferentially facilitating the return of the cell to the Earth surface via precipitation that would provide moisture for cell growth (Sands et al., 1982; Morris et al., 2008). Thus, natural biological selection could reinforce the relationship between microbiology and atmospheric processes via utilization of particle coatings.

\section{Conclusions}

In the AMAZE-08 campaign we deployed a UV-APS to measure supermicron fluorescent biological aerosol particles in real-time, while particles were also collected onto filters for SEM/EDX, NanoSIMS, and staining microscopy analyses. Here we summarize our five key conclusions: 


\section{Biological and non-biological particles have distinct sources and trends of abundance allowing for separated detection}

FBAP concentrations remained relatively constant throughout the entire campaign and had a strong and consistent diurnal cycle: lowest during the day, rising after sunset, and peaking in the early morning several hours before sunrise. The daily trend is likely a combination of the dilution effect due to an increase in the atmospheric boundary layer height during the afternoon and cycles in primary particle release from forest biota. Although these data cannot quantitatively elucidate daily influences of meteorology or biology, the consistent decrease in FBAP several hours before the increase in incoming solar radiation, temperature, or humidity (Fig. S3) and the contrasting pattern to total particles both suggest that daily patterns in biological activity were strongly involved.

The FBAP size distribution peaked at $2.3 \mu \mathrm{m}$ in number and in a set of multi-modal peaks in mass from 2 to $5 \mu \mathrm{m}$, whereas the distribution of total particles was consistently dominated by a submicron peak. An average of approximately $24 \%$ of the integrated coarse particle number $(47 \%$ of particle mass) consisted of fluorescent biological particles, though these values are only a lower limit proxy for PBAP concentrations, because not all biological material fluoresces at the combination of excitation and emission wavelengths used (Pöhlker et al., 2012a). FBAP fractions were consistently greater than $60 \%$ in number and $80 \%$ in mass during morning concentration peaks. Combining information from UV-APS and electron microscopy, the remaining fraction of non-fluorescent aerosol was shown to be comprised mostly of mineral dust, non-fluorescent biological material, and inorganic salts, in decreasing order of concentration.

\section{Biological particles in the Amazon are important frac- tions of supermicron aerosol and should be considered} when investigating biosphere-atmosphere interactions

Spores of fungi and yeast cells are the most likely candidates to explain the dominant mode of coarse FBAP and PBAP observed here. This observation is consistent with reports from many locations that suggest fungal spores contribute significantly to airborne PBAP concentrations (e.g., Graham et al., 2003a; Elbert et al., 2007; Fröhlich-Nowoisky et al., 2009; Zhang et al., 2010), measured diurnal evidence indicative of spore release (see Sect. 3.3), and the consistency of the size distributions across analysis types here. Among commonly considered classes of PBAP, pollen particles are typically too large $(8-100 \mu \mathrm{m})$, although intracellular fragments could be involved. Pollen is usually observed in lower numbers at night, however, and so pollen fragments are not likely to be the cause of the strong diurnal cycle. While some types of bacteria have been shown to be present in higher numbers at night, single bacterial cells are probably too small $(\sim 1 \mu \mathrm{m})$ to be the primary contributor to observations here. The 2$3 \mu \mathrm{m}$ FBAP material could be agglomerates of bacterial cells, but these were not commonly observed by SEM analysis and thus unlikely to dominate the PBAP fraction. Fragments of plant and insect matter are also likely to be a fraction of the observed PBAP at these sizes, but were also not observed in large numbers through qualitative image analysis. Rigorous determination of the nature of the particles within the FBAP/PBAP fraction sampled was not possible from this analysis, however, and it is likely that they comprise a diverse mixture of biogenic particle types (Artaxo et al., 1990). Correlations with meteorological variables were performed; temperature and relative humidity were most strongly correlated with FBAP. Other relationships were observed to be relatively weak.

Many species of fungal spores span the range of sizes involved here, and many have been shown to be ejected preferentially at night. Among the most common types of fungal spores worldwide include several genera whose size is within the target range here. For example Pasanen et al. (1991) discussed the relationship of spore size with RH and showed the range of $D_{\mathrm{a}}$ for selected Cladosporium $(1.6-4.6 \mu \mathrm{m})$, Penicillium $(2.3-3.9 \mu \mathrm{m})$, and Aspergillus $(2.0-2.6 \mu \mathrm{m})$ species. Kanaani et al. (2008b) further showed, using the UV-APS as a detector, that species of Penicillium and Aspergillus exhibited mean $D_{\mathrm{a}}$ of 2.5 and $3.5 \mu \mathrm{m}$, respectively. Even in the case that a member of one of these fungal spore genera were the most likely candidate to comprise the peak modes observed here, classification based on size alone would not be possible, because spore size is strongly a function not only of species, but of fungal age as well as environmental and growth factors. Daily patterns of FBAP peaks well before sunrise, shown here and previously, suggest the observed FBAP are not likely Cladosporium, but are rather basidiospores and ascospores (Troutt and Levetin, 2001; Burch and Levetin, 2002; Jones and Harrison, 2004).

In addition to observations by multiple techniques of supermicron biological particles, samples analyzed by electron microscopy consistently revealed submicron particles in Amazonian filter samples. These may have been either nonfungal in nature, or spores from fungal-like species lacking chitin-based cell walls (e.g. organisms of the Chromalveolata kingdom such as plant-pathogenic Phytophthora spp.) and may also regularly escape detection by many techniques. In total, the observations here further the suggestion of many previous reports that biological particles constitute a key class of supermicron aerosol, but a comparison with concentration values determined by other techniques underscores the difficulty of inter-comparing PBAP estimates. 


\section{Biological particles are frequently coated with a mixture of organic and inorganic compounds}

While mineral dust particles were generally observed to be uncoated, biological and pyrogenic particles on filter samples were often observed with mixed organic-inorganic coatings up to $1 \mu \mathrm{m}$ or more in thickness. Contrasting examples of one coated and one uncoated biological particle were shown. Qualitative observations using NanoSIMS suggests that liquid coatings on PBAP are enriched in inorganic elements such as $\mathrm{K}, \mathrm{N}, \mathrm{S}$, and $\mathrm{Cl}$, and could be primary liquids ejected with fungal spores from their source. However, agglomeration with secondary organic aerosol whose growth was seeded from small primary biological particles containing the observed inorganic salts is the more likely coating mechanism (Pöhlker et al., 2012b). Mixed organic-inorganic coatings shown preferentially on PBAP and pyrogenic particles provide a hygroscopic chemical surface that may allow such particles to be efficient GCCN, especially in regions like the Amazon, so dominated by PBAP in the coarse mode. These coatings may provide benefit for the cells involved by protecting against harmful solar radiation and desiccation, and thus may have been utilized by microorganisms for evolutionary gain of species fitness (Morris et al., 2010).

\section{The UV-APS instrument is successfully able to detect biological particles, with some limitations}

FBAP had a consistent daily pattern with repeatable size distributions and concentration, despite episodic periods of high mineral dust influence to the total aerosol. This suggests that the UV-APS is able to successfully discriminate between mineral dust and biological particles. In limited laboratory study certain SOA particles have been shown to fluoresce (Bones et al., 2010). Submicron particles within the Amazon region are dominated by secondary organic material (Chen et al., 2009; Martin et al., 2010a; Pöschl et al., 2010; Schneider et al., 2011), and a high fraction of supermicron particles analyzed by SEM were observed here to be coated with liquid organic material. Thus, the presence of large amounts of secondary organic material suggests that this material could contribute to fluorescence detected by the UV-APS and determined to be FBAP. The anti-correlation of time series of organic concentrations (Chen et al., 2009) and FBAP concentrations (peaking in the afternoon and early morning, respectively) suggests that SOA is at least not the primary source of fluorescent particles in this study, however. Further, qualitative comparison of size and shape of size distributions of fluorescent particles measured by the UV-APS with those from filters analyzed by SEM and staining microscopy validates earlier suggestions that FBAP can be considered a lowerlimit value of PBAP in many situations.
FBAP determination is instrument- and excitation wavelength-specific and, as measured by the UV-APS, can be considered only a lower-limit of PBAP, however, because some biological particles exhibit fluorescence below the instrument detection limit. Other LIF-based bioaerosol sensors should be evaluated individually with respect to their ability to detect all PBAP classes, but care should be taken not to equate FBAP and PBAP without more detailed consideration. Non-fluorescent particles observed during periods of high FBAP concentration included biological particles exhibiting very weak fluorescence, a suggestion corroborated by comparison of $\sim 2 \mu \mathrm{m}$ particles analyzed by SEM. Electron microscopy also revealed biological particles $0.5-1.0 \mu \mathrm{m}$ in size that were too small to fluoresce strongly within the UV-APS.

In situations where the quoted statements by BellPedersen et al. (1996; Sect. 3.3) are true, the UV-APS and other similar real-time autofluorescence techniques could, in some cases, preferentially detect relatively transparent basidiospores whose thin cell walls allow the interrogating laser pulse to excite fluorescence without significant light absorption.

More collocated deployments of complementary PBAP measurement techniques will help to clarify remaining uncertainties in observations presented here. Additional studies including detailed microscopy along with DNA techniques will be able to elucidate biological species causing observed dominant PBAP trends. Detailed understanding of PBAP fluxes will also be useful to better model biological emissions from different environment types in order to estimate possible impacts on cloud formation.

\section{Supplementary material related to this article is available online at: http://www.atmos-chem-phys.net/12/ 11997/2012/acp-12-11997-2012-supplement.pdf.}

Acknowledgements. The work has been supported by the Max Planck Society and the LEC Geocycles Mainz, Germany. J. A. Huffman acknowledges internal faculty funding from the University of Denver, and P. Artaxo acknowledges funding from FAPESP (Thematic project AEROCLIMA 2008/58100-2) and CNPg. We acknowledge support from the LBA Central Office and INPA (Instituto Nacional de Pesquisas da Amazonia), and the INPI-MPI team for logistical support. The authors gratefully acknowledge support by J. Fröhlich-Nowoisky, A. Wollny, C. Pöhlker, W. Elbert, V. Després, G. C. Roberts, A. J. Prenni, M. Petters, C. Morris, the AMAZE-08 team, and supporting institutions.

The service charges for this open access publication have been covered by the Max Planck Society.

Edited by: J. Schneider 


\section{References}

Abdel-Hameed, A. A., Khoder, M. I., Yuosra, S., Osman, A. M., and Ghanem, S.: Diurnal distribution of airborne bacteria and fungi in the atmosphere of Helwan area, Egypt, Sci. Total Environ., 407, 6217-6222, doi:10.1016/j.scitotenv.2009.08.028, 2009.

Adams, K. F., Hyde, H. A., and Williams, D. A.: Woodlands as a Source of Allergens, Allergy, 23, 265-281, doi:10.1111/j.13989995.1968.tb04059.x, 1968.

Agranovski, V., Ristovski, Z., Hargreaves, M., Blackall, P. J., and Morawska, L.: Real-time measurement of bacterial aerosols with the UVAPS: performance evaluation, J. Aerosol Sci., 34, 301317, doi:10.1016/s0021-8502(02)00181-7, 2003a.

Agranovski, V., Ristovski, Z., Hargreaves, M., Blackall, P. J., and Morawska, L.: Performance evaluation of the UVAPS: influence of physiological age of airborne bacteria and bacterial stress, J. Aerosol Sci., 34, 1711-1727, doi:10.1016/s00218502(03)00191-5, 2003b.

Andreae, M. O.: Aerosols before pollution, Science, 315, 50-51, doi:10.1126/science.1136529, 2007.

Andreae, M. O. and Crutzen, P. J.: Atmospheric Aerosols: Biogeochemical Sources and Role in Atmospheric Chemistry, Science, 276, 1052-1058, doi:10.1126/science.276.5315.1052, 1997.

Andreae, M. O., Artaxo, P., Brandao, C., Carswell, F. E., Ciccioli, P., da Costa, A. L., Culf, A. D., Esteves, J. L., Gash, J. H. C., Grace, J., Kabat, P., Lelieveld, J., Malhi, Y., Manzi, A. O., Meixner, F. X., Nobre, A. D., Nobre, C., Ruivo, M., Silva-Dias, M. A., Stefani, P., Valentini, R., von Jouanne, J., and Waterloo, M. J.: Biogeochemical cycling of carbon, water, energy, trace gases, and aerosols in Amazonia: The LBA-EUSTACH experiments, J. Geophys. Res.-Atmos., 107, 8066, doi:10.1029/2001jd000524, 2002.

Ariya, P. A. and Amyot, M.: New Directions: The role of bioaerosols in atmospheric chemistry and physics, Atmos. Environ., 38, 1231-1232, doi:10.1016/j.atmosenv.2003.12.006, 2004.

Artaxo, P. and Hansson, H. C.: Size Distribution of Biogenic Aerosol - Particles from the Amazon Basin, Atmos. Environ., 29, 393-402, 1995.

Artaxo, P., Storms, H., Bruynseels, F., Vangrieken, R., and Maenhaut, W.: Composition and Sources of Aerosols form the Amazon Basin, J. Geophys. Res.-Atmos., 93, 1605-1615, 1988.

Artaxo, P., Maenhaut, W., Storms, H., and Van Grieken, R.: Aerosol Characteristics and Sources for the Amazon Basin During the Wet Season, J. Geophys. Res., 95, 16971-16985, doi:10.1029/JD095iD10p16971, 1990.

Attard, E., Yang, H., Delort, A.-M., Amato, P., Pöschl, U., Glaux, C., Koop, T., and Morris, C. E.: Effects of atmospheric conditions on ice nucleation activity of Pseudomonas, Atmos. Chem. Phys., 12, 10667-10677, doi:10.5194/acp-12-10667-2012, 2012.

Avis, P. G., Dickie, I. A., and Mueller, G. M.: A “dirty" business: testing the limitations of terminal restriction fragment length polymorphism (TRFLP) analysis of soil fungi, Mol. Ecol., 15, 873-882, doi:10.1111/j.1365-294X.2005.02842.x, 2006.

Bartnicki-Garcia, S.: Cell Wall Chemistry, Morphogenesis, and Taxonomy of Fungi, Annu. Rev. Microbiol., 22, 87-108, doi:10.1146/annurev.mi.22.100168.000511, 1968.

Barahona, D., West, R. E. L., Stier, P., Romakkaniemi, S., Kokkola, H., and Nenes, A.: Comprehensively accounting for the effect of giant $\mathrm{CCN}$ in cloud activation parameterizations, Atmos. Chem. Phys., 10, 2467-2473, doi:10.5194/acp-10-2467-2010, 2010.
Battarbee, J. L., Rose, N. L., and Long, X. Z.: A continuous, high resolution record of urban airborne particulates suitable for retrospective microscopical analysis, Atmos. Environ., 31, 171-181, 1997.

Bauer, H., Schueller, E., Weinke, G., Berger, A., Hitzenberger, R., Marr, I. L., and Puxbaum, H.: Significant contributions of fungal spores to the organic carbon and to the aerosol mass balance of the urban atmospheric aerosol, Atmos. Environ., 42, 5542-5549, doi:10.1016/j.atmosenv.2008.03.019, 2008.

Bell-Pedersen, D., Garceau, N., and Loros, J. J.: Circadian rhythms in fungi, J. Genet., 75, 387-401, 1996.

Bones, D. L., Henricksen, D. K., Mang, S. A., Gonsior, M., Bateman, A. P., B., N. T., Cooper, W. J., and Nizkorodov, S. A.: Appearance of strong absorbers and fluorophores in limonene$\mathrm{O}_{3}$ secondary organic aerosol due to $\mathrm{NH}_{4}^{+}$-mediated chemical aging over long time scales, J. Geophys. Res., 115, D05203, doi:10.1029/2009JD012864, 2010.

Bowers, R. M., Lauber, C. L., Wiedinmyer, C., Hamady, M., Hallar, A. G., Fall, R., Knight, R., and Fierer, N.: Characterization of Airborne Microbial Communities at a High-Elevation Site and Their Potential To Act as Atmospheric Ice Nuclei, Appl. Environ. Microbiol., 75, 5121-5130, doi:10.1128/AEM.00447-09, 2009.

Brosseau, L. M., Vesley, D., Rice, N., Goodell, K., Nellis, M., and Hairston, P.: Differences in detected fluorescence among several bacterial species measured with a direct-reading particle sizer and fluorescence detector, Aerosol Sci. Technol., 32, 545-558, 2000.

Burch, M. and Levetin, E.: Effects of meteorological conditions on spore plumes, Int. J. Biometeorol., 46, 107-117, doi:10.1007/s00484-002-0127-1, 2002.

Burge, H. A.: Some Comments on the Aerobiology of Fungus Spores, Grana, 25, 143-146, 1986.

Burrows, S. M., Butler, T., Jöckel, P., Tost, H., Kerkweg, A., Pöschl, U., and Lawrence, M. G.: Bacteria in the global atmosphere - Part 2: Modeling of emissions and transport between different ecosystems, Atmos. Chem. Phys., 9, 9281-9297, doi:10.5194/acp-9-9281-2009, 2009a.

Burrows, S. M., Elbert, W., Lawrence, M. G., and Pöschl, U.: Bacteria in the global atmosphere - Part 1: Review and synthesis of literature data for different ecosystems, Atmos. Chem. Phys., 9, 9263-9280, doi:10.5194/acp-9-9263-2009, 2009b.

Calderon, C., Lacey, J., McCartney, H. A., and Rosas, I.: Seasonal and Diurnal Variation of Airborne Basidiomycete Spore Concentrations in Mexico City, Grana, 34, 260-268, 1995.

Chen, Q., Farmer, D. K., Schneider, J., Zorn, S. R., Heald, C. L., Karl, T. G., Guenther, A., Allan, J. D., Robinson, N., Coe, H., Kimmel, J. R., Pauliquevis, T., Borrmann, S., Poschl, U., Andreae, M. O., Artaxo, P., Jimenez, J. L., and Martin, S. T.: Mass spectral characterization of submicron biogenic organic particles in the Amazon Basin, Geophys. Res. Lett., 36, L20806, doi:10.1029/2009g1039880, 2009.

Cox, C. S. and Wathes, C. M.: Bioaerosols Handbook, Lewis Publishers, Boca Raton, FL, 1995.

Coz, E., Artíñano, B., Clark, L. M., Hernandez, M., Robinson, A. L., Casuccio, G. S., Lersch, T. L., and Pandis, S. N.: Characterization of fine primary biogenic organic aerosol in an urban area in the northeastern United States, Atmos. Environ., 44, 39523962, doi:10.1016/j.atmosenv.2010.07.007, 2010. 
De Groot, R. C.: Diurnal cycles of airborne spores produced by forest fungi, Phytopathology, 58, 1223-1229, 1968.

DeCarlo, P., Slowik, J. G., Worsnop, D., Davidovits, P., and Jimenez, J.: Particle Morphology and Density Characterization by Combined Mobility and Aerodynamic Diameter Measurements. Part 1: Theory, Aerosol Sci. Tech., 38, 1185-1205, doi:10.1080/027868290903907, 2004.

Després, V. R., Huffman, J. A., Burrows, S. M., Hoose, C., Safatov, A. S., Buryak, G. A., Fröhlich-Nowoisky, J., Elbert, W., Andreae, M. O., Pöschl, U., and Jaenicke, R.: Primary Biological Aerosol Particles in the Atmosphere: A Review, Tellus B, 64, 15598, doi:10.3402/tellusb.v64i0.15598, 2012.

Ebben, C. J., Martinez, I. S., Shrestha, M., Buchbinder, A. M., Corrigan, A. L., Guenther, A., Karl, T., Petäjä, T., Song, W. W., Zorn, S. R., Artaxo, P., Kulmala, M., Martin, S. T., Russell, L. M., Williams, J., and Geiger, F. M.: Contrasting organic aerosol particles from boreal and tropical forests during HUMPPA-COPEC2010 and AMAZE-08 using coherent vibrational spectroscopy, Atmos. Chem. Phys., 11, 10317-10329, doi:10.5194/acp-1110317-2011, 2011.

Echalar, F., Artaxo, P., Martins, J. V., Yamasoe, M., Gerab, F., Maenhaut, W., and Holben, B.: Long-term monitoring of atmospheric aerosols in the Amazon Basin: Source identification and apportionment, J. Geophys. Res., 103, 31849-31864, doi:10.1029/98jd01749, 1998.

Elbert, W., Taylor, P. E., Andreae, M. O., and Pöschl, U.: Contribution of fungi to primary biogenic aerosols in the atmosphere: wet and dry discharged spores, carbohydrates, and inorganic ions, Atmos. Chem. Phys., 7, 4569-4588, doi:10.5194/acp-7-4569-2007, 2007.

Eng, J., Lynch, R. M., and Balaban, R. S.: Nicotinamide Adenine Dinucleotide Fluorescence Spectroscopy and Imaging of Isolated Cardiac Myocytes, Biophys. J., 55, 621-630, 1989.

Fröhlich-Nowoisky, J., Pickersgill, D. A., Després, V. R., and Pöschl, U.: High diversity of fungi in air particulate matter, P. Natl. Acad. Sci., 106, 12814-12819, doi:10.1073/pnas.0811003106, 2009.

Gabey, A. M., Gallagher, M. W., Whitehead, J., Dorsey, J. R., Kaye, P. H., and Stanley, W. R.: Measurements and comparison of primary biological aerosol above and below a tropical forest canopy using a dual channel fluorescence spectrometer, Atmos. Chem. Phys., 10, 4453-4466, doi:10.5194/acp-10-4453-2010, 2010.

Gabey, A. M., Stanley, W. R., Gallagher, M. W., and Kaye, P. H.: The fluorescence properties of aerosol larger than $0.8 \mu \mathrm{m}$ in urban and tropical rainforest locations, Atmos. Chem. Phys., 11, 5491-5504, doi:10.5194/acp-11-5491-2011, 2011.

Garland, R. M., Schmid, O., Nowak, A., Achtert, P., Wiedensohler, A., Gunthe, S. S., Takegawa, N., Kita, K., Kondo, Y., Hu, M., Shao, M., Zeng, L. M., Zhu, T., Andreae, M. O., and Pöschl, U.: Aerosol optical properties observed during Campaign of Air Quality Research in Beijing 2006 (CAREBeijing2006): Characteristic differences between the inflow and outflow of Beijing city air, J. Geophys. Res.-Atmos., 114, D00G04, doi:10.1029/2008jd010780, 2009.

Gilardoni, S., Vignati, E., Marmer, E., Cavalli, F., Belis, C., Gianelle, V., Loureiro, A., and Artaxo, P.: Sources of carbonaceous aerosol in the Amazon basin, Atmos. Chem. Phys., 11, 27472764, doi:10.5194/acp-11-2747-2011, 2011.
Gilbert, G. S.: Nocturnal fungi: Airborne spores in the canopy and understory of a tropical rain forest, Biotropica, 37, 462-464, doi:10.1111/j.1744-7429.2005.00061.x, 2005.

Gottwald, T. R., Trocine, T. M., and Timmer, L. W.: A computercontrolled environmental chamber for the study of aerial fungal spore release, Phytopathology, 87, 1078-1084, 1997.

Graham, B., Guyon, P., Maenhaut, W., Taylor, P. E., Ebert, M., Matthias-Maser, S., Mayol-Bracero, O. L., and Godoi, R. H. M.: Composition and diurnal variability of the natural Amazonian aerosol, J. Geophys. Res., 108, 4765, doi:10.1029/2003JD004049, 2003a.

Graham, B., Guyon, P., Taylor, P. E., Artaxo, P., Maenhaut, W., Glovsky, M. M., Flagan, R. C., and Andreae, M. O.: Organic compounds present in the natural Amazonian aerosol: Characterization by gas chromatography-mass spectrometry, J. Geophys. Res.-Atmos., 108, 4766, doi:10.1029/2003jd003990, 2003 b.

Griffin, D. W., Kubilay, N., Kocak, M., Gray, M. A., Borden, T. C., and Shinn, E. A.: Airborne desert dust and aeromicrobiology over the Turkish Mediterranean coastline, Atmos. Environ., 41, 4050-4062, doi:10.1016/j.atmosenv.2007.01.023, 2007.

Gunthe, S. S., King, S. M., Rose, D., Chen, Q., Roldin, P., Farmer, D. K., Jimenez, J. L., Artaxo, P., Andreae, M. O., Martin, S. T., and Pöschl, U.: Cloud condensation nuclei in pristine tropical rainforest air of Amazonia: size-resolved measurements and modeling of atmospheric aerosol composition and CCN activity, Atmos. Chem. Phys., 9, 7551-7575, doi:10.5194/acp-9-75512009, 2009.

Guyon, P., Graham, B., Roberts, G. C., Mayol-Bracero, O. L., Maenhaut, W., Artaxo, P., and Andreae, M. O.: In-canopy gradients, composition, sources, and optical properties of aerosol over the Amazon forest, J. Geophys. Res.-Atmos., 108, 4591, doi:10.1029/2003jd003465, 2003.

Hairston, P. P., Ho, J., and Quant, F. R.: Design of an instrument for real-time detection of bioaerosols using simultaneous measurement of particle aerodynamic size and intrinsic fluorescence, J. Aerosol Sci., 28, 471-482, 1997.

Hallar, A. G., Chirokova, G., McCubbin, I., Painter, T. H., Wiedinmyer, C., and Dodson, C.: Atmospheric bioaerosols transported via dust storms in the western United States, Geophys. Res. Lett., 38, L17801, doi:10.1029/2011g1048166, 2011.

Harrison, D. E. and Chance, B.: Fluorimetric Technique for Monitoring Changes in Level of Reduced Nicotinamide Nucleotides in Continuous Cultures of Microorganisms, Appl. Microbiol., 19, 446-450, 1970.

Harriss, R. C., Garstang, M., Wofsy, S. C., Beck, S. M., Bendura, R. J., Coelho, J. R. B., Drewry, J. W., Hoell, J. M., Jr., Matson, P. A., McNeal, R. J., Molion, L. C. B., Navarro, R. L., Rabine, V., and Snell, R. L.: The Amazon Boundary Layer Experiment: Wet Season 1987, J. Geophys. Res., 95, 16721-16736, doi:10.1029/JD095iD10p16721, 1990.

Heald, C. L. and Spracklen, D. V.: Atmospheric budget of primary biological aerosol particles from fungal spores, Geophys. Res. Lett., 36, L09806, doi:10.1029/2009g1037493, 2009.

Healy, D. A., O'Connor, D. J., Burke, A. M., and Sodeau, J. R.: A laboratory assessment of the Waveband Integrated Bioaerosol Sensor (WIBS-4) using individual samples of pollen and fungal spore material, Atmos. Environ., 60, 534-543, doi:10.1016/j.atmosenv.2012.06.052, 2012. 
Helbert, W., Sugiyama, J., Ishihara, M., and Yamanaka, S.: Characterization of native crystalline cellulose in the cell walls of Oomycota, J. Biotechnol., 57, 29-37, doi:10.1016/s01681656(97)00084-9, 1997.

Helbig, N., Vogel, B., Vogel, H., and Fiedler, F.: Numerical modelling of pollen dispersion on the regional scale, Aerobiologia, 20, 3-19, doi:10.1023/b:aero.0000022984.51588.30, 2004.

Hirst, J. M.: Changes in atmospheric spore content: Diurnal periodicity and the effects of weather, Transactions of the British Mycological Society, 36, 375-393, doi:10.1016/s00071536(53)80034-3, 1953.

Hoose, C., Kristjansson, J. E., and Burrows, S. M.: How important is biological ice nucleation in clouds on a global scale?, Environ. Res. Lett., 5, 024009, doi:10.1088/1748-9326/5/2/024009, 2010.

Huber, L. and Gillespie, T. J.: Modeling Leaf Wetness in Relation to Plant Disease Epidemiology, Annu. Rev. Phytopathol., 30, 553577, 1992.

Huffman, J. A., Treutlein, B., and Pöschl, U.: Fluorescent biological aerosol particle concentrations and size distributions measured with an Ultraviolet Aerodynamic Particle Sizer (UVAPS) in Central Europe, Atmos. Chem. Phys., 10, 3215-3233, doi:10.5194/acp-10-3215-2010, 2010.

Huffman, J. A., Pöhlker, C., Prenni, A. J., DeMott, P. J., Mason, R. H., Robinson, N. H., Fröhlich-Nowoisky, J. F., Tobo, Y., Després, V., Garcia, E., Gochis, D. J., Harris, E., Müller-Germann, I., Ruzene, C., Sinha, B., Day, D. A., Andreae, M. O., Jimenez, J. L., Gallavardin, S., Kreidenweis, S. M., Bertram, A. K., and Pöschl, U.: High concentrations of biological aerosol particles and ice nuclei during rain, Atmos. Chem. Phys. Discuss., in preparation, 2012.

Jaenicke, R., Matthias-Maser, S., and Gruber, S.: Omnipresence of biological material in the atmosphere, Environ. Chem., 4, $217-$ 220, doi:10.1071/en07021, 2007.

Jones, A. M. and Harrison, R. M.: The effects of meteorological factors on atmospheric bioaerosol concentrations - a review, Sci. Total Environ., 326, 151-180, doi:10.1016/j.scitotenv.2003.11.021, 2004.

Jones, M. D. M., Forn, I., Gadelha, C., Egan, M. J., Bass, D., Massana, R., and Richards, T. A.: Discovery of novel intermediate forms redefines the fungal tree of life, Nature, 474, 200-203, http://www.nature.com/nature/journal/v474/n7350/abs/10. 1038-nature09984-unlocked.html\#supplementary-information, 2011.

Judelson, H. S. and Blanco, F. A.: The spores of Phytophthora: weapons of the plant destroyer, Nat. Rev. Micro, 3, 47-58, 2005.

Jung, J. H., Lee, J. E., Hwang, G. B., Lee, B. U., Lee, S. B., Jurng, J. S., and Bae, G. N.: Electrospray-Assisted Ultraviolet Aerodynamic Particle Sizer Spectrometer for Real-time Characterization of Bacterial Particles, Anal. Chem., 82, 664-671, doi:10.1021/ac902189n, 2010.

Kanaani, H., Hargreaves, M., Ristovski, Z., and Morawska, L.: Performance assessment of UVAPS: Influence of fungal spore age and air exposure, J. Aerosol Sci., 38, 83-96, doi:10.1016/j.jaerosci.2006.10.003, 2007.

Kanaani, H., Hargreaves, M., Ristovski, Z., and Morawska, L.: Deposition rates of fungal spores in indoor environments, factors effecting them and comparison with non-biological aerosols, Atmos. Environ., 42, 7141-7154, doi:10.1016/j.atmosenv.2008.05.059, 2008a.
Kanaani, H., Hargreaves, M., Smith, J., Ristovski, Z., Agranovski, V., and Morawska, L.: Performance of UVAPS with respect to detection of airborne fungi, J. Aerosol Sci., 39, 175-189, doi:10.1016/j.jaerosci.2007.10.007, 2008b.

Kaye, P. H., Stanley, W. R., Hirst, E., Foot, E. V., Baxter, K. L., and Barrington, S. J.: Single particle multichannel bio-aerosol fluorescence sensor, Opt. Express, 13, 3583-3593, 2005.

Kenny, C. M. and Jennings, S. G.: Background bioaerosol measurements at Mace Head, J. Aerosol Sci., 29, S779-S780, doi:10.1016/S0021-8502(98)90572-9, 1998.

Laflamme, C., Verreault, D., Lavigne, S., Trudel, L., Ho, J., and Duchaine, C.: Autofluorescence as a viability marker for detection of bacterial spores, Front. Biosci., 10, 1647-1653, 2005.

Lee, B. U., Jung, J. H., Yun, S. H., Hwang, G. B., and Bae, G. N.: Application of UVAPS to real-time detection of inactivation of fungal bioaerosols due to thermal energy, J. Aerosol Sci., 41, 694-701, doi:10.1016/j.jaerosci.2010.04.003, 2010.

Li, J. K., Asali, E. C., and Humphrey, A. E.: Monitoring Cell Concentration and Activity by Multiple Excitation Flourometry, Biotechnol. Progr., 7, 21-27, 1991.

Lin, W.-H. and Li, C.-S.: Size Characteristics of Fungus Allergens in the Subtropical Climate, Aerosol Sci. Technol., 25, 93-100, doi:10.1080/02786829608965382, 1996.

Lin, W.-H. and Li, C.-S.: Associations of Fungal Aerosols, Air Pollutants, and Meteorological Factors, Aerosol Sci. Tech., 32, 359368, doi:10.1080/027868200303678, 2000.

Martin, S. T., Andreae, M. O., Althausen, D., Artaxo, P., Baars, H., Borrmann, S., Chen, Q., Farmer, D. K., Guenther, A., Gunthe, S. S., Jimenez, J. L., Karl, T., Longo, K., Manzi, A., Müller, T., Pauliquevis, T., Petters, M. D., Prenni, A. J., Pöschl, U., Rizzo, L. V., Schneider, J., Smith, J. N., Swietlicki, E., Tota, J., Wang, J., Wiedensohler, A., and Zorn, S. R.: An overview of the Amazonian Aerosol Characterization Experiment 2008 (AMAZE08), Atmos. Chem. Phys., 10, 11415-11438, doi:10.5194/acp10-11415-2010, 2010a.

Martin, S. T., Andreae, M. O., Artaxo, P., Baumgardner, D., Chen, Q., Goldstein, A. H., Guenther, A., Heald, C. L., Mayol-Bracero, O. L., McMurry, P. H., Pauliquevis, T., Pöschl, U., Prather, K. A., Roberts, G. C., Saleska, S. R., Silva Dias, M. A., Spracklen, D. V., Swietlicki, E., and Trebs, I.: Sources and properties of Amazonian aerosol particles, Rev. Geophys., 48, RG2002, doi:10.1029/2008rg000280, 2010b.

Matthias-Maser, S. and Jaenicke, R.: The size distribution of primary biological aerosol particles with radii $>0.2 \mu \mathrm{m}$ in an urban rural influenced region, Atmos. Res., 39, 279-286, 1995.

Matthias-Maser, S. and Jaenicke, R.: The size distribution of primary biological aerosol particles in the multiphase atmosphere, Aerobiologia, 16, 207-210, 2000.

McCartney, H. A. and Lacey, M. E.: The Production and Release of Ascospores in Pyrenopeziza-Brassicae on Oilseed Rape, Plant Pathol., 39, 17-32, 1990.

Miguel, A. G., Taylor, P. E., House, J., Glovsky, M. M., and Flagan, R. C.: Meteorological influences on respirable fragment release from Chinese elm pollen, Aerosol Sci. Tech., 40, 690-696, doi:10.1080/02786820600798869, 2006.

Möhler, O., DeMott, P. J., Vali, G., and Levin, Z.: Microbiology and atmospheric processes: the role of biological particles in cloud physics, Biogeosciences, 4, 1059-1071, doi:10.5194/bg-4-10592007, 2007. 
Morris, C. E., Sands, D. C., Vinatzer, B. A., Glaux, C., Guilbaud, C., Buffiere, A., Yan, S., Dominguez, H., and Thompson, B. M.: The life history of the plant pathogen Pseudomonas syringae is linked to the water cycle, ISME J., 2, 321-334, 2008.

Morris, C. E., Sands, D. C., Vanneste, J. L., Montarry, J., Oakley, B., Guilbaud, C., and Glaux, C.: Inferring the Evolutionary History of the Plant Pathogen Pseudomonas syringae from Its Biogeography in Headwaters of Rivers in North America, Europe, and New Zealand, mBio, 1, e00107-10, doi:10.1128/mBio.00107-10, 2010.

Morris, C. E., Sands, D. C., Glaux, C., Samsatly, J., Asaad, S., Moukahel, A. R., Gonçalves, F. L. T., and Bigg, E. K.: Urediospores of Puccinia spp. and other rusts are warm-temperature ice nucleators and harbor ice nucleation active bacteria, Atmos. Chem. Phys. Discuss., 12, 26143-26171, doi:10.5194/acpd-1226143-2012, 2012.

Oliveira, M., Ribeiro, H., Delgado, J., and Abreu, I.: The effects of meteorological factors on airborne fungal spore concentration in two areas differing in urbanisation level, Int. J. Biometeorol., 53, 61-73, doi:10.1007/s00484-008-0191-2, 2009.

Pady, S. M., Kramer, C. L., and Clary, R.: Periodicity in Spore Release in Cladosporium, Mycologia, 61, 87-98, 1969.

Pan, Y.-L., Hill, S. C., Pinnick, R. G., House, J. M., Flagan, R. C., and Chang, R. K.: Dual-excitation-wavelength fluorescence spectra and elastic scattering for differentiation of single airborne pollen and fungal particles, Atmos. Environ., 45, 1555-1563, doi:10.1016/j.atmosenv.2010.12.042, 2011.

Pasanen, A. L., Pasanen, P., Jantunen, M. J., and Kalliokoski, P.: Significance of air humidity and air velocity for fungal spore release into the air, Atmos. Environ. A-Gen., 25, 459-462, doi:10.1016/0960-1686(91)90316-y, 1991.

Paulitz, T. C.: Diurnal release of ascospores by Gibberella zeae in inoculated wheat plots, Plant Dis., 80, 674-678, 1996.

Petersen, A. B. and Rosendahl, S.: Phylogeny of the Peronosporomycetes (Oomycota) based on partial sequences of the large ribosomal subunit (LSU rDNA), Mycol. Res., 104, 12951303, doi:10.1017/s0953756200003075, 2000.

Pinnick, R. G., Hill, S. C., Nachman, P., Pendleton, J. D., Fernandez, G. L., Mayo, M. W., and Bruno, J. G.: Fluorescence Particle Counter for Detecting Airborne Bacteria and Other Biological Particles, Aerosol Sci. Tech., 23, 653-664, 1995.

Pöhlker, C., Huffman, J. A., and Pöschl, U.: Autofluorescence of atmospheric bioaerosols - fluorescent biomolecules and potential interferences, Atmos. Meas. Tech., 5, 37-71, doi:10.5194/amt-537-2012, 2012a.

Pöhlker, C., Wiedemann, K. T., Sinha, B., Shiraiwa, M., Gunthe, S. S., Smith, M., Su, H., Artaxo, P., Chen, Q., Cheng, Y., Elbert, W., Gillles, M. K., Kilcoyne, A. L. D., Moffet, R. C., Weigand, M., Martin, S. T., Pöschl, U., and Andreae, M. O.: Biogenic potassium salt particles as seeds for secondary organic aerosol in the Amazon, Science, 337, 1075-1078, 2012b.

Pöhlker, C., Huffman, J. A., Förster, J. D. and Pöschl, U.: Autofluorescence of pollen, Atmos. Meas. Tech. Discuss., in preparation, 2012c.

Polymenakou, P. N., Mandalakis, M., Stephanou, E. G., and Tselepides, A.: Particle size distribution of airborne microorganisms and pathogens during an intense African dust event in the eastern Mediterranean, Environ. Health Perspect., 116, 292-296, doi:10.1289/ehp.10684, 2008.
Pöschl, U.: Atmospheric aerosols: Composition, transformation, climate and health effects, Angew. Chem. Int. Edit., 44, 7520 7540, doi:10.1002/anie.200501122, 2005.

Pöschl, U., Martin, S. T., Sinha, B., Chen, Q., Gunthe, S. S., Huffman, J. A., Borrmann, S., Farmer, D. K., Garland, R. M., Helas, G., Jimeney, J. L., King, S. M., Manzi, A., Mikhailov, E., Pauliquevis, T., Petters, M. D., Prenni, A. J., Roldin, P., Rose, D., Schneider, J., Su, H., Zorn, S. R., Artaxo, P., and Andreae, M. O.: Rainforest Aerosols as Biogenic Nuclei of Clouds and Precipitation in the Amazon, Science, 329, 15131516, doi:10.1126/science.1191056, 2010.

Potts, M.: Desiccation tolerance: a simple process?, Trends Microbiol., 9, 553-559, doi:10.1016/S0966-842X(01)02231-4, 2001.

Prenni, A. J., Petters, M. D., Kreidenweis, S. M., Heald, C. L., Martin, S. T., Artaxo, P., Garland, R. M., Wollny, A. G., and Pöschl, U.: Relative roles of biogenic emissions and Saharan dust as ice nuclei in the Amazon basin, Nat. Geosci., 2, 402-405, doi:10.1038/ngeo517, 2009.

Prenni, A. J., Tobo, Y., Garcia, E., DeMott, P. J., Huffman, J. A., McCluskey, C. S., Kreidenweis, S. M., Prenni, J. E., Pöhlker, C., and Pöschl, U.: The impact of rain on ice nuclei populations at a forested site in Colorado, Geophys. Res. Lett., accepted, 2012.

Pringle, A., Patek, S. N., Fischer, M., Stolze, J., and Money, N. P.: The captured launch of a ballistospore, Mycologia, 97, 866-871, 2005.

Reponen, T., Grinshpun, S. A., Conwell, K. L., Wiest, J., and Anderson, M.: Aerodynamic versus physical size of spores: Measurement and implication for respiratory deposition, Grana, 40, 119-125, 2001.

Rissler, J., Vestin, A., Swietlicki, E., Fisch, G., Zhou, J., Artaxo, P., and Andreae, M. O.: Size distribution and hygroscopic properties of aerosol particles from dry-season biomass burning in Amazonia, Atmos. Chem. Phys., 6, 471-491, doi:10.5194/acp6-471-2006, 2006.

Rockett, T. R. and Kramer, C. L.: Periodicity and Total Spore Production by Lignicolous basidiomycetes, Mycologia, 66, 817829, 1974.

Sands, D. C., Langhans, V. E., Scharen, A. L., and de Smet, G.: The association between bacteria and rain and possible resultant meteorological implications, Journal of the Hungarian Meteorological Service, 86, 148-152, 1982.

Schneider, J., Freutel, F., Zorn, S. R., Chen, Q., Farmer, D. K., Jimenez, J. L., Martin, S. T., Artaxo, P., Wiedensohler, A., and Borrmann, S.: Mass-spectrometric identification of primary biological particle markers and application to pristine submicron aerosol measurements in Amazonia, Atmos. Chem. Phys., 11, 11415-11429, doi:10.5194/acp-11-11415-2011, 2011.

Schnell, R. C. and Vali, G.: Atmospheric Ice Nuclei from Decomposing Vegetation, Nature, 236, 163-165, 1972.

Schnell, R. C. and Vali, G.: World-wide Source of Leaf-derived Freezing Nuclei, Nature, 246, 212-213, 1973.

Seaver, M., Eversole, J. D., Hardgrove, J. J., Cary, W. K., and Roselle, D. C.: Size and fluorescence measurements for field detection of biological aerosols, Aerosol Sci. Tech., 30, 174-185, 1999.

Sesartic, A. and Dallafior, T. N.: Global fungal spore emissions, review and synthesis of literature data, Biogeosciences, 8, 11811192, doi:10.5194/bg-8-1181-2011, 2011. 
Sesartic, A., Lohmann, U., and Storelvmo, T.: Bacteria in the ECHAM5-HAM global climate model, Atmos. Chem. Phys., 12, 8645-8661, doi:10.5194/acp-12-8645-2012, 2012.

Sinha, B. W., Hoppe, P., Huth, J., Foley, S., and Andreae, M. O.: Sulfur isotope analyses of individual aerosol particles in the urban aerosol at a central European site (Mainz, Germany), Atmos. Chem. Phys., 8, 7217-7238, doi:10.5194/acp-8-7217-2008, 2008.

Sivaprakasam, V., Huston, A. L., Scotto, C., and Eversole, J. D.: Multiple UV wavelength excitation and fluorescence of bioaerosols, Opt. Express, 12, 4457-4466, 2004.

Stanley, W. R., Kaye, P. H., Foot, V. E., Barrington, S. J., Gallagher, M., and Gabey, A.: Continuous bioaerosol monitoring in a tropical environment using a UV fluorescence particle spectrometer, Atmos. Sci. Lett., 12, 195-199, doi:10.1002/asl.310, 2011.

Taylor, P. E., Flagan, R. C., Miguel, A. G., Valenta, R., and Glovsky, M. M.: Birch pollen rupture and the release of aerosols of respirable allergens, Clin. Exp. Allergy, 34, 1591-1596, doi:10.1111/j.1365-2222.2004.02078.x, 2004.

Tong, Y. and Lighthart, B.: Diurnal distribution of total and culturable atmospheric bacteria at a rural site, Aerosol Sci. Technol., 30, 246-254, 1999.

Troutt, C. and Levetin, E.: Correlation of spring spore concentrations and meteorological conditions in Tulsa, Oklahoma, Int. J. Biometeorol., 45, 64-74, doi:10.1007/s004840100087, 2001.

Tuch, T. M., Haudek, A., Müller, T., Nowak, A., Wex, H., and Wiedensohler, A.: Design and performance of an automatic regenerating adsorption aerosol dryer for continuous operation at monitoring sites, Atmos. Meas. Tech., 2, 417-422, doi:10.5194/amt-2-417-2009, 2009.
Wang, C. C., Fang, G. C., and Lee, L. Y.: The study of ambient air bioaerosols during summer daytime and nighttime periods in Taichung, Central Taiwan, Environ.l Forensics, 9, 6-14, doi:10.1080/15275920701729175, 2008.

Whitehead, J. D., Gallagher, M. W., Dorsey, J. R., Robinson, N., Gabey, A. M., Coe, H., McFiggans, G., Flynn, M. J., Ryder, J., Nemitz, E., and Davies, F.: Aerosol fluxes and dynamics within and above a tropical rainforest in South-East Asia, Atmos. Chem. Phys., 10, 9369-9382, doi:10.5194/acp-10-9369-2010, 2010.

Wiedinmyer, C., Bowers, R. M., Fierer, N., Horanyi, E., Hannigan, M., Hallar, A. G., McCubbin, I., and Baustian, K.: The contribution of biological particles to observed particulate organic carbon at a remote high altitude site, Atmos. Environ., 43, 4278-4282, doi:10.1016/j.atmosenv.2009.06.012, 2009.

Wittmaack, K., Wehnes, H., Heinzmann, U., and Agerer, R.: An overview on bioaerosols viewed by scanning electron microscopy, Sci. Total Environ., 346, 244-255, doi:10.1016/j.scitotenv.2004.11.009, 2005.

Womack, A. M., Bohannan, B. J. M., and Green, J. L.: Biodiversity and biogeography of the atmosphere, Philos. T. R. Soc. B, 365, 3645-3653, doi:10.1098/rstb.2010.0283, 2010.

Yankofsky, S. A., Levin, Z., Bertold, T., and Sandlerman, N.: Some Basic Characteristics of Bacterial Freezing Nuclei, J. Appl. Meteorol., 20, 1013-1019, doi:10.1175/15200450(1981)020<1013:SBCOBF>2.0.CO;2, 1981.

Zhang, T., Engling, G., Chan, C. Y., Zhang, Y. N., Zhang, Z. S., Lin, M., Sang, X. F., Li, Y. D., and Li, Y. S.: Contribution of fungal spores to particulate matter in a tropical rainforest, Environ. Res. Lett., 5, 024010, doi:10.1088/1748-9326/5/2/024010, 2010. 